\title{
Assessing traffic-generated "dread" risk
}

\author{
Alan G. Hallsworth \\ Professor of Geography, Staffordshire University, UK \\ Colin Black \\ Researcher, University of Portsmouth, UK \\ David Evans, Rodney Tolley \\ Senior Lecturers in Geography, Staffordshire University, UK
}

The decision process behind observed individual behaviour is known to be a complex one. This is especially so when aspects of that same behaviour are apparently contradictory. Introduces a measurement scale for revealing underlying motivations for behaviour. Focuses on the trip to school by car; apparently favoured by individuals on safety grounds, however, it also leads to extra trips and therefore increases car-borne pollution. Tests the scale in a survey involving British geography undergraduates.
World Transport Policy \&

Practice

2/ 4 [1996] 3-7

(c) MCB University Press

[ISSN 1352-7614]

\section{Introduction}

In this paper we focus on the problems generated by the propensity of British parents to take their children to school by car. This is an example of how, whilewe "think global" in the face of common environmental problems, we also "act local": producing local outcomes that can vary consi derably. The numbers of children being driven to school in Britain are well ahead of those in other countries despite there ostensibly being a common awareness of Dread Risk (Slovic, 1987) from car-borne pollutants. Clearly, common problems are mediated by local circumstance: but how to analyse the problem? Since Slovic put cargenerated risks alongsi de other major risks including nuclear war, and since reactions to nuclear war risk have been well documented, we seek in this paper to draw some analogies. We use existing nuclear war work (Hallsworth, 1987) that showed how individuals used psychological "coping mechanisms" in the face of perceived threats.

We relate this to the trip to school by asking which issues are at the for efront of one's mind when such trips are contemplated - and which are pushed to the deeper recesses. We know that there are cross-national differences in this process because, as all trafficrelated issues have risen in salience (Goodwin et al., 1992; Tolley 1990; Whitelegg, 1993) so the types of cross-national differences in responses also reported in the nuclear threat work (Hallsworth, 1987, p. 293) have again become evident. This is particularly clear from A nglo-German cross-national work by Hillman et al. (1990) - yet only recently (Tranter and Whitelegg, 1994) has new empirical evidence been produced to compare with the original work. It is especially of note that the school-trip problem has been responded to in a particular way in Britain: "saferoutes" and "walk-to-school" initiatives being announced (Tolley, 1995). Our basi c question is this: When we think of "safety", from which risk are we seeking to protect ourselves (and our children)?
The journey to school

Recent figures suggest that, in Britain, some 30 per cent of all peak-hour car trips involve journeys to school and it is cur rently suggested that a full 25 per cent of all car trips made by British schoolchildren are trips to school. General contextual factors to the trip to school have recently been discussed (Bradshaw, 1995) though only li mited infor mation seems to be available on the travel habits of the youngest school children (for example, Black and Hallsworth, 1994). We find the Hillman et al. (1990) researches to be very inter esting for one particular reason: there is, in the Hillman work, a clear expression of how little real danger there is to child's well being on a walk to school. Ger mans seem to accept this since most small children walk to school without an adult (Hillman et al., 1990, p. 52). Indeed, at the age of seven, the rati o between German and English children allowed to walk to school alone is 8:1 (Hillman, 1993, p. 14) This British "avoi dance tactic" is a common one that has a direct parallel in work on crime: 81 per cent of British people who feel very unsafe because of crime fears never go out alone at night on foot (Mirlees-Black and Maung, 1994, p. 2). When a child is taken to school, does the parent think first of the environment, of personal convenience, cost, etc., or of road safety issues? Certainly, others have shown that there is more than one problem for parents:

Children... have particular problems coping with traffic ...and... fears of assault and molestation (Tranter and Whi tel egg, 1994, p. 265).

The pioneering work by Hillman et al. is therefore impor tant to us because it reinforces thelikelihood that decisions are made on the basis of beliefs, perceptions and intuitions ... as most studies of crime fear have shown (Williams and Dickinson, 1993). It must, therefore, be that the British parents are not examining rational, objective, facts but are basing decisions on other criteria. 
Alan G. Hallsworth,

Colin Black, David Evans and

Rodney Tolley

Assessing traffic-generated

"dread" risk

World Transport Policy \&

Practice

2/4 [1996] 3-7

\section{A pilot study on car usage for school trips}

The long-ter $m$ ai $m$ of thi s research is to target the parents of children attending primary/ infant schools in Britain. Such schools will typi cally cover the age range of 4-8years: known to have little awareness of risks from traffic. It is logical to assume that parents with cars will be most tempted to escort children of this age to school by car. In order to gain test information from this general cohort, 276 parents at a primary school in Hampshire, England, were sent a questionnaire on car usage for the trip to school. Overall, 188 parents responded (68 per cent), and results showed overwhelmingly that if a car was available for the school trip then it was used. This contrasts markedly with the results for the older cohort in Germany ( a country with higher per capita car ownership) where over 80 per cent of 9-year-olds walked to school without an adult (Tranter and Whi telegg, 1994, p. 269).

When the parents were asked to explain their reasons, half said the child was too young to walk al one and 28 per cent regarded the roads as too busy for child safety. When asked why "other people" might use the car for the trip to school, 20 per cent of respondents thought that those "other people" might feel that the child was safer in the car. Some were genuinely fearful for the safety of their child despite evidence that (other than for robbery) "strangers" are not responsible for a high proportion of violent crime. Clearly, the notion of generally-accepted societal norms and of the expectation that other parents, other adults, even the police, areacting in loco parentis in public situations has gone into steep declinein Britain. This is in contrast to Germany where

The German Ianguage contains the words Kinderundfreudlichkeit ... general unfriendliness towards children ... an attitude... which is observable. Ger man children out al one are much more under the general supervision of adults on the street whom parents know can, and will ... act in loco parentis (Hillman et al., 1990, p. 84)

In contrast, we feel that British parents have increasingly retreated into i solation - perhaps haunted by the image of the childmurderer Myra Hindley. Popular media representations are that British streets are desperately unsafe for children.

Societal nor ms are clearly very powerful and yet are notoriously difficult to quantify. We suggest that outcomes at the national scaleare likely to be a mixture of the elusive concept of "national characteristics" plus some influence from the built environment.
Equally, the British propensity to drive may reflect a structural under-provision of pricecompetitive transport alter natives that are perceived as safe. Our focus is on the "coping mechanisms" that allow peoplementally to "run away from" a threatening environment.

Preparation of a measurement scale for coping with threat

What we can now present is some evidence on how a scale for the measurement of "coping" mechanisms was devised - and the first results obtained. In the nuclear war work, much time was devoted to deriving a scale for the measurement of psychological coping mechanisms. It was felt that six reactions emerged in the face of the dread risk of nuclear war and the same general notion of "coping" is used with the new trafficrelated scale. It is not necessary to cover again the for mulation of the scale as this is outlined in Hallsworth (1987). The six “mechanisms", many of them very familiar, are these:

1 "Helplessness" (or more commonly "powerlessness").

2 The "wiser heads" defence. Abrogating responsibility to a higher, wiser, authority - usually the government.

3 "Displacement". Here the threat is the fault of a third party that is responsi ble for (or is deliberately overstating) the probIem.

4 Denial of risk (often, it is "habituation" rather than "denial").

5 "Vulnerability"; thi s si mply reflects, those who face up to the threat and really do fear it (strictly not coping).

6 "Activism". We must be aware that activism is a coping mechanism and there are many groups of "anti-road" protesters in Britain.

All the statements that made up the original scale were constructed from phrases taken from newspapers, political statements or research findings (Grinspoon, 1964). The familiarity of the phrases attested to their relevance as descriptors of attitudes towards the threat of nuclear war (see the version in Hallsworth 1987, p. 291). It was felt that the scale had proved itself to be robust so, in order to focus on key traffic-related worries, the phrases were simply modified to fit the threat under study. The first version of the adapted scale is shown in the statistical analysis presented in Tablel. 
Alan G. Hallsworth,

Colin Black, David Evans and

Rodney Tolley

Assessing traffic-generated

"dread" risk

World Transport Policy \&

Practice

2/ 4 [1996] 3-7 $\overline{\text { Table I }}$

Principal components loadings on "coping" scale

Component loadings

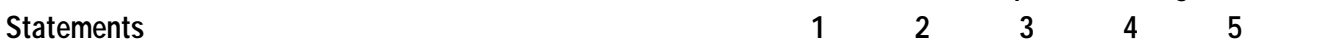

People spend too much time worrying about pollution

It is morally acceptable to commit a small crime on a

construction site in order to protest against the greater

crime of environmental destruction

When getting children to school, nowhere is safer than

in the car

Protest is pointless, you will never get a government to

change its policy - unless it wants to

The government will act long before traffic problems

get out of hand

But for the so-called "greens", society would not be worrying about pollution

You could die tomorrow - car accidents are just another everyday risk

On environmental issues, you just have to trust the government

The world has far more cars than is sensible

I have never seen any local evidence of pollution caused by cars

There are so many cars now; you could be hurt in an accident tomorrow

The human race can overcome any obstacle to progress

I am far too busy to worry about environmental issues

The car is with us forever

I feel a moral duty to preserve the planet from pollution damage

If I don't use the roads - someone else will

Cars are part of a good lifestyle

I expect that at some future date this country will have severe pollution problems

Cars can be designed that will totally eliminate pollution

It is not my responsibility to worry about the environment

Car manufacturers produce new models and then they attempt to sell them to the public - whether they are really needed or not

Nothing I do makes any difference to the environment, one way or another

People overestimate risks from traffic - plenty of people survive car accidents

"Greens" stir up all the so-called environmental campaigns

Problems with car fumes are getting out of control

If my job caused environmental problems, I'd rather be unemployed than carry on causing pollution

It is naïve to believe we could ever ban cars totally

Our government should ensure that this country takes the lead on environmental issues

Catalytic converters will turn out to be just another expensive gimmick foisted on car-buyers
0.64

6

0.51

0.51

$-0.41$

0.61

0.56

0.71

$-0.54$

$-0.63$

0.61

0.50

0.56

0.63

\section{A pilot study}

A pil ot survey was attempted using undergraduates in Geography at the University of Portsmouth, England. We have no reason to suppose that Geographers are more sensiti zed than others to such issues and we regard these preliminary findings as most encouraging.

\section{Results}

A coping scale was, then, modified from the nuclear war scale previously used and "threat" questionnaires were presented to undergraduate geographers in a controlled, classroom situation. A total of 29 statements or propositions on traffic-related topi cs were presented as a semantic differential test. The 
Alan G. Hallsworth,

Colin Black, David Evans and

Rodney Tolley

Assessing traffic-generated

"dread" risk

World Transport Policy \&

Practice

2/4 [1996] 3-7 respondents were a roughly equal mix of males and females and were mostly aged 18-21. Overall, 300 responses were received.

As in the previous studies, the assumption was made that the six for ms of coping mechanism should emerge as six separate or distinct di mensions of the overall opi nions held by the cohort. Principal Components Factor A nalysis (PCA) was ther efore again used.

\section{Data analysis}

The results obtained after varimax rotation of the six largest components are shown in Table I which indicates the actual questions that were used and also shows the strongest "Ioadings" on each of the six components.

\section{Component one}

Component one is primarily a reflection of "denial", which contains the dismissive elements of "bei ng too busy" to concern oneself with something. The component is not, however, a clear-cut one since we cannot deny somelinks to statements that were included to denote "hel plessness" or "nothing I can do". Perhaps, then, there are two for ms of powerlessness. One is powerlessness in face of a major dread, a threat against which no individual action has any meaningful effect. However, as we have argued el sewhere (Hallsworth et al., 1995) some actions might need to be taken collectively. An individual is ther efore equally powerless if he or she can see what actions could betaken collectively but does not believe that anyone in power is actually going to facilitate them. We gai $n$ a sense of these two for ms of hel plessness in this component and we will return to them again later.

\section{Component two}

This is vulnerability. As in the earlier work on nuclear war, this is the component for those who believe that a catastrophic outcome could happen, and who are afraid.

\section{Component three}

We earlier expressed the beli ef that the concept of the "threatening enemy" is more difficult to articulate with environmental topics. We feel that what is under threat from the envi ronmentalists is the car-based lifestylethe freedoms to drive wherever one wants, whenever one wants.

\section{Component four}

The variables loading strongly here are clearly the personal moral issues. There is no obvious expectation that personal moral values will be espoused by the powers of central gover nment. The counter point is, of course, pure self interest “If I don't use the roads - someone el se will".

\section{Component five}

This is the higher authority or "wiser heads" defence. The respondent beli eves that someone else has the responsibility and knowledge to act. The individual is thus absolved from personal responsibility by virtue of having elected someone el se to take collective responsibility.

\section{Component six}

Helplessness is more prominent here than in component one though the cross-links to "denial" remain. In defining hel plessness, this component rel ates more to component five than to issues of envi ronmental pollution per se This form of hel plessness is really political powerlessness in a country with no regional government at all and where local democracy is at the whim of an all-powerful centre.

\section{Overall conclusions}

Our feeling is that the results merit further development of the scale. Multiple inter pretations may be partly responsible for the emergence of noti ons of "powerlessness" on more than one component and this can be modified. A further key point is that the issue of child safety on the trip to school - a perceived "British" preoccupation - did not load significantly on any component. This is by no means a problem since the cohort completing the questionnaire comprised undergraduates. Typically these are young people aged 18-21 and very few of the respondents would have any responsibility for children at all. We know that this variable will perform more strongly with parents of small children. Overall, we think that the "British problem" is a hybrid. The global concerns are quietly pushed to the back of one's mind as "too awful to think about". However, instead of relying on safety in numbers, the fear of the image of child-murderers is reinforcing the withdrawal of children from the streets. As the herd immunity slips away, we seek refuge in the car; leaving those on the streets increasingly isolated. We beli eve that the same "coping mechanisms" that were used in the face of the threat of nuclear war are being utilized again: as shown in this pilot work with British geography undergraduates. It will now be used with parents as the subjects.

\section{References}

Black, C. and Hallsworth, A.G. (1994), Traffic around Primary Schools: What Is theScale of theProblem?, SIRC Transport Group working paper, University of Portsmouth. 
Alan G. Hallsworth,

Colin Black, David Evans and

Rodney Tolley

Assessing traffic-generated

"dread" risk

World Transport Policy \&

Practice

2/ 4 [1996] 3-7
Bradshaw, R. (1995), "Why do parents drive their children to school?", Traffic Enginering and Control, Vol. 36 No. 1, pp. 16-19.

Goodwin, P., Hallett, S., Kenny, F. and Stokes, G. (1992), Transport - TheNew Realism, Transport Studies Unit, Oxford.

Grinspoon, L. (1964), “The unacceptability of disqui eting facts", in Grosser, L. (Ed.), The Threat of I mpending Disaster, MIT Press, Harvard.

Hallsworth, A.G. (1987), "Some cross-national differences in the perception of the threat of nuclear war: The Netherlands, France, West Germany", Tijdschrift voor Economischeen SocialeGeografie, Vol. 78 No. 4, pp. 290-6.

Hallsworth, A.G., Tolley, R. and Black, C. (1995), "Psycho-social dimensions of public quiescence towards risks from traffic-generated atmospheric pollution", J ournal of Transport Geography, Vol. 3No. 1, pp. 39-51.

Hillman, M. (Ed.) (1993), Children, Transport and theQuality of Life, PSI Press, London.

Hillman, M., A dams, J . and Whitelegg, J . (1990), OneFalseMove, PSI Press, London.
Mirlees-Black, C. and Maung, N. (1994), "Fear of crime: findings from the 1992 British Crime Survey", HomeResearch Findings 9, Office Research and Statistics Department, London. Seligman, M.E.P. (1975), Hel plessness: on Depression, Development and Death, Freeman, San Francisco, CA.

Slovic, P. (1987), "Perception of risk", Science, Vol. 236, pp. 280-4

Tolley, R. (Ed.) (1990), TheGreening of Urban Transport, Belhaven, London.

Tolley, R. (1995), “Developing safe routes to school", paper presented to PTRC Summer School on Transport Safety Issues, London, February.

Tranter, C. and Whitelegg, J . (1994), “Children's travel behaviour in Canber ra; car-dependent lifestyles in a low-density city", J ournal of Transport Geography, Vol . 2, pp. 265-73.

Whitelegg, J . (1993), Transport for a Sustainable Future, Belhaven, London.

Williams, P. and Dickinson, J . (1993), “Fear of crime: read all about it", British J ournal of Criminology, Vol. 33 No. 1, pp. 33-56. 


\title{
The impact of improved ferry services on an island economy: the case of Mull
}

\author{
Hugh M. Begg \\ Consultant Economist and Town Planner, St Andrews Economic Consultants, UK \\ Bob Henderson \\ Government Economist, Scottish Office Agriculture and Fisheries Department, UK \\ Peter Tyler \\ Fellow of St Catherine's College, Department of Land Economy, \\ University of Cambridge, UK \\ Colin Warnock \\ Consultant Economist, Segal Quince Wicksteed Ltd, Cambridge, UK
}

Sets out the methodology developed to establish the impact of an enhanced ferry service on the Island of Mull in Scotland. The work on which it is based was undertaken for the (former) Scottish Office Industry Department in co-operation with Highlands and Islands Enterprise and Caledonian Macbrayne Ltd. Their principal concern was the impact of operating and capital subsidies made available to Cal Mac as operator of services throughout the Western Isles. The research improves understanding of ways in which transport infrastructure can enhance the prospects for remote rural communities and the local economies on which they depend.

This paper throws new light on research undertaken by the authors in collaboration with colleagues at St Andrews Economic Consultants, PA Cambridge Economic Consultants, and the Scottish Office Industry Department. The authors acknowledge the key contributions to the work presented here of Tony Jackson and Stuart McDowall.

World Transport Policy \&

Practice

2/ 4 [1996] 8-12

(c) MCB University Press

[ISSN 1352-7614]

\section{Introduction}

This paper sets out the methodology developed to establish the impact of an enhanced ferry service on the Island of Mull in Scotland. The work on which it is based was undertaken as part of two major pieces of research for the Scottish Office Industry Department and Highlands and Islands Enter prise in co-operation with Caledonian MacBrayne Ltd (CalM ac). Their concern was the impact on island communities off the West Coast of Scotland of the operating and capital subsi dies made avai lable for the provision of fer ry services (Scotti sh Office, 1993a; 1994). The research represents an attempt on the part of the research team to hel $p$ to improve understanding of the impact of enhanced transport infrastructure provision on remoterural economies. The authors beli eve this to be a relatively underresearched topic, which is surprising given the substantial volume of public expenditure being committed to such measures by both nati onal governments and the European Commission.

Mull, with a land area of some 90,000 hectares and a population of around 2,700 is located off the west coast of Scotland at the southern end of the Firth of Lorne. Following almost a century of continuing decline the past decade has seen a reversal of the trend as fewer younger people leave in search of work and growing numbers of returning Muilleachans and others retire to the island. However the resi dent populati on is still not sufficient to sustain a large service sector. The manufacturing sector is al so very small and is mainly based on food and drink and craftbased production. Thus Mull remains heavily dependent on its natural resources which are the basis for the agriculture, fishing, and forestry sectors as well as the developing tourist industry which is the largest sector of the economy.

From earliest historical times the economy of Mull has been dependent on easy access by sea. In 1880 the Caledonian railway was extended to Oban and from there a fer ry service, provided by David MacBrayne Ltd to the island capital of Tober mory, linked Mull to the economy of Central Scotland. The basis of the current network of services was laid with the opening in 1964 of the Craignure pier in the south east of Mull and the contemporaneous setting up of a road haulage distribution service to handle goods to and from the mainland.

A series of enhancements to the fer ry services was undertaken by the operators Caledonian MacBrayne Ltd over the period 1988 to 1991. These are summarized in Table I. The consequences were substantial improvements in the road and ferry network. The Tober moray/ Kilchoan link, with only around 3 per cent of the total traffic, is of local significance. More important was the upgrading of the Fishnish/Lochaline service which accounts for around 28 per cent of vehicle car ryings. However, of greatest significance for traffic and potential economic impacts were the improvements to the Oban to Craignure crossings which account for over 80 per cent of passengers and almost 70 per cent of vehicle movements.

Research objectives and data sources

The objectives for the research reported on here were to establi sh the changes in carryings to and from Mull attributable to the fer ry service enhancements; to estimate the impacts of the changes in traffic flow on the local economy; and to consider the extent to which the increased traffic flows and their associated expenditure were diverted from other nearby areas.

CalMac provided infor mation on the carryings of the fer ry services (including capacity, frequency and vol ume of passengers/ vehicles/ freight moved) before and after the upgrading. These data were critical in the estimation of the impact of the improvements to ferry services. 
Hugh M. Begg,

Bob Henderson, Peter Tyler

and Colin Warnock

The impact of improved ferry

services on an island

economy: the case of Mull

World Transport Policy \&

Practice

2/ 4 [1996] 8-12 $\overline{\text { Table I }}$

Enhancements to ferry services between the mainland and Mull

\begin{tabular}{|c|c|c|}
\hline Ferry service/ change & Outcome & $\begin{array}{l}\text { Date of } \\
\text { change }\end{array}$ \\
\hline
\end{tabular}

Replacement of vessel with another with higher Increased carrying capacity for vehicles (from

April 1988

clearance for commercial vehicles, no

deadweight restrictions and greater capacity

45 in summer, 55 in winter to 80 all year round),

larger commercial vehicles can be carried and

greater total cargo deadweight

Lochaline/ Fishnish

Increase in size of vessel, drive through vessel

Increased capacity for cars, from six to 12 cars in August winter and six to 18 cars in summer; drive through 1986

Tobermory/ Kilchoan

Introductory of vehicle-carrying ferry following

provision of slipways. Substantial increase in

New vehicle route to Mull with six cars per sailing

April 1991 services

In order to establish the impact of the net effect of changes in the fer ry carryings, it was necessary to under take fieldwork relating to both the demand and supply sides of the local economy. For the demand-side, a survey of over 1,000 passengers on the fer ry service allowed estimates to be made of the volumes of different types of visitors, their spending profiles and trip duration of their visits. Infor mation on resi dent trips off-island was also acquired and was used to estimate displacement of activity from $\mathrm{Mull}$ as a result of the improvements in fer ry services. The passenger survey also provided the information required to calculate the extent to which the benefits for Mull were at the expense of other nearby local economies. On the supplyside, a survey of 30 local businesses provided indications of changes in economi c activity in the local area.

The problem of the peak and modelling the effects of ferry service enhancements

The peaking of seasonal, weekly and daily demand, with consi derable excess capacity at other times, is a common problem in transport economics. It is these peaks which determi ne the need for an enhancement of supply which typically must be kept operational during periods of slack demand. Exami nation of the trends in ferry carryings to and from Mull revealed an extreme example of "the problem of the peak". It was a consequence of the seasonal patter $n$ of tourist traffic between Mull (including lona) and the Mainland, and the concentrati on during the tourist season of most traffic on a limited number of crossings between Oban and Crai gnure. Thus, the summer season of 16 weeks accounts for around 60 per cent of total passengers and
55 per cent of vehicles. These movements are fur ther concentrated on the morning crossing from Oban and the evening retur $n$ from Craignure.

It was attractive for policy makers and the ferry operators to try to smooth the pattern of demand through the use of differential pricing, aggressive marketing and related policies. However experience demonstrated that the scope was limited in the face of the underlying trends in consumer behaviour and notably those of day-trippers and tourists. The only realistic alter native was an increase in ferry capacity to meet peak demand.

In modelling the effect of service enhancements we expected that the reli ef of constrai ned/ discouraged demand would be followed by an immediate increase in carryings: the "new facility" effect. In addition, longer ter m dynamic benefits would arise from the opening of the market to new sources of demand. This "enhanced capacity" effect would emerge as the routes accommodated their share of the growth in traffic within the wider ferry network as a whole. This would be deter mined by regional and national trends in carryings. Finally, there was the "island specific" effect: changes in carryings which emerge as a consequence of developments particular to the individual local economy.

Our approach to the estimation of the "new facility" and "enhanced capacity" effects is illustrated in Figure 1. The continuous line represents the first step which was to produce a summary of actual carryings. This demonstrated the impact of capacity constraints and the result of their relaxation following the introduction of improved services. The second step was to estimate what the growth in carryings would have been if there had been no capacity constraint in the first place and 
Hugh M. Begg,

Bob Henderson, Peter Tyler

and Colin Warnock

The impact of improved ferry

services on an island

World Transport Policy \&

Practice

2/ 4 [1996] 8-12 economy: the case of Mull

carryings had been freeto grow at the same rate as the rest of the Western I sles fer ry network (the WIN growth rate). For this purpose the actual carryings were projected forward using the WIN growth rate. The third step was to estimate what the carryings would have been if the service enhancement had not taken place, (i.e. the counterfactual situation). If appropriate pricing, promotional and rationing schemes could have been introduced to smooth the patter $\mathrm{n}$ of seasonal, weekly and daily demand then growth mi ght have continued using existing spare capacity at much the same rate as in the period just before the enhancements came into operation. However, it seemed likely these could not be introduced, and very little growth would be possible. We had to make a judgment of where within these two estimates of constrained growth the most likely path would lie. The final step was to identify "one-off" past and likely future changes in the local economy with significant impacts on traffic generation. We concluded that in this case the deleteri ous and beneficial impacts balanced one another. However it is important that they could have had an important influence on the counterfactual situation one way or another.

Table Il summarizes our estimates of the additional carryings to and from Mull over the period 1986 to 1992 attri butable to ferry enhancements.

Measuring the impact of improved ferry services on the economy of Mull

Thestarting point for our estimation of the impact of improved ferry services on the economy of Mull was to recall that producers and consumers on the island incur costs in their day-to-day transactions which they

$\overline{\text { Figure 1. }}$

Modelling the effects of ferry service enhancements

Carryings

A: Effects of ferry improvements in relieving constrained and discouraged demand (short-term "new facility" effect) Actual carryings Carryings at WIN growth - rate - Carryings at constrained growth rate

B: Effect of ferry improvement in permitting route to share in unconstrained network growth (longterm "enhanced capacity" effect)

$\begin{array}{ccc}\begin{array}{c}\text { Constraints } \\ \text { appear }\end{array} & \begin{array}{c}\text { Service } \\ \text { enhanced }\end{array} & \begin{array}{c}\text { Current } \\ \text { year }\end{array}\end{array}$

$\overline{\text { Table II }}$

Estimating the additional vehicle carryings attributable to improved ferry services to Mull: 1986-1992

\begin{tabular}{lcc}
\hline & Cars (000s) & Coaches \\
\hline a: 1986 vehicle carryings & 76.0 & 716 \\
b: Additional carryings on the & & \\
$\quad$ assumption of constrained & & \\
$\quad$ growth 1987-92 & +14.7 & +535 \\
c: Total constrained carryings & & \\
$\quad \begin{array}{l}1992 \text { (a+b) } \\
\text { d: Actual carryings 1992 }\end{array}$ & 90.7 & 1,251 \\
e: Extra carryings attributable & & 2,293 \\
$\quad$ to service improvements (d-c) & & \\
of which: & +33.1 & $+1,042$
\end{tabular}

f: "Enhanced capacity effect" (additional carryings on the assumption of WIN growth rate 1987-92) a

g: "New facility effect" (e-f)

Note: ${ }^{~}$ The gains from enhanced capacity will continue beyond 1992, until capacity constraints re-emerge

would not incur if they lived on the mainland. Other things being equal they experiencea higher cost of living. Having to use a ferry also has an impact on those producers and consumers who wish to engage in trade. An obvious example (of particular importance in the case of M ull) is the demand attributable to tourists who wish to visit the island. The important point is that changes in the characteristics of a fer ry service, such as price, frequency or capacity (all of which can be translated into changes in cost) affect the island economy in a number of ways. From an economic point of view, they are all reducible to supply-side or demand-side effects on island output. The for mer are transmitted through the cost curves of individual island producers. Thelatter are transmitted through the demands of purchasers, both on and off the island, for the output of island producers.

The analysis was advanced further by dividing economic activity into that relating to export markets; and that which supplies the requirements of resi dents. Output of the former category is a function of demand off the island; and output of the latter is I argely deter mined by the sizeand income of the resident population. It is crucial that the ability of the island economy to achieve growth in incomes is largely dependent on the ability to export. In the Mull context this means the ability to attract tourists.

The direct effects of improving the quality of a ferry service on the export activity of tourism are relatively easy to conceptualize. By increasing capacity and reducing delays, 
Hugh M. Begg,

Bob Henderson, Peter Tyler

and Colin Warnock

The impact of improved ferry

services on an island

economy: the case of Mull

World Transport Policy \&

Practice

2/ 4 [1996] 8-12 it makes the island more accessible to tourists. Other things being equal, more tourists will be inclined to visit the island. In technical terms, the demand curve for tourists to the island is shifted outwards, as the preferences of potential tourists change (in other words, for a given ferry pricestructure, because these other factors have changed, there would be a higher level of demand). Thi s impact on tourist activity can be expected to come through relatively quickly, although the extent to which it leads to additional output and employment effects on the island is dependent on the amount of sur plus capacity, particularly in the labour force, in the sectors concer ned.

Within the context set by this analysis we establi shed the expenditure of visitors from surveys of ferry users, interviewed at their point of departure from Mull. This survey was also used to derive figures for average occupancy rates for car-bor ne traffic (2.6), for average total spend per head on Mull and I ona by day-visitors ( $£ 12$ ) and for average daily spend per head by staying visitors ( $£ 34)$, as well as for the share of day and stay visitors in each category. We appli ed a conservative estimate of 30 occupants per coach. The rel evant calculations are summarized in Table III. This provides data on total expenditure by the addi tional visitors attracted to Mull as a result of improvements to the ferry services.

Although the open nature of any island economy (including that of Mull) means that leakages are high, increased activity in an export sector can be expected to generate additional demand in domestic activities with further beneficial effects on output and employment in the sectors concerned. With this in mind we applied the local tourism multipliers obtained for Skye (Scottish Office, 1993b) to the visitor expenditure esti mates obtained from the passenger surveys. Although it has a rather larger population Skye provides a reasonable parallel to the Mull economy, both in terms of its dependence on tourism, and in its accessi bility to the Scottish mainland.

These results suggest that ferry enhancements were responsi ble for injecting $£ 3.5$ million in additional tourism expenditure into the Mull economy in 1992. This generated an additional $\mathrm{fl}$ million in local income and supported 124 full-time equivalent (FTE) jobs. In addition, this extra activity on Mull supported a fur ther 30FTE jobs elsewhere in the Scottish economy. In order to place this contribution in the context, the total contribution of tourism to the Mull economy in 1992 was calculated, by applying the same procedures. It is estimated that tourist expenditure on Mull and I ona amounted to $f 15.4$ million in 1992, generating $\mathrm{f} 4.5 \mathrm{million}$ in local income. This sustained a total of 544FTE jobs in the Mull economy, and a further 132 in the rest of the Scottish economy. Economic activities, including provision of accommodation, attractions, retailing and specialist manufacturers, all gained from the increase in tourism.

\begin{tabular}{|c|c|c|}
\hline & Cars & Coaches \\
\hline \multicolumn{3}{|l|}{ Additional CalMac traffic carryings } \\
\hline (excluding residents) & 31,444 & 1,042 \\
\hline Number of trips to Mull ( $=0.5 \times$ carryings) & 15,722 & 521 \\
\hline \multicolumn{3}{|l|}{ Number of passengers carried (average 2.6 per car, } \\
\hline $\begin{array}{l}30 \text { per } \text { coach) = additional visitors } \\
\text { of which: }\end{array}$ & 40,877 & 15,630 \\
\hline Day visitors ( 27 per cent car, 98 per cent coach) & 11,037 & 15,317 \\
\hline Stay visitors ( 73 per cent car, 2 per cent coach) & 29,840 & 313 \\
\hline $\begin{array}{l}\text { Total expenditure day visitors }(26,354 \times f 12 \text { average } \\
\text { spend per head) }\end{array}$ & \multicolumn{2}{|c|}{$f 316,248$} \\
\hline \multicolumn{3}{|l|}{ Total expenditure stay visitors $(30,153 \times £ 34.3$} \\
\hline $\begin{array}{l}\text { average spend per head } x \text { average length of stay } 3.1 \text { for car } \\
\text { users, } 2.8 \text { for coach users) }\end{array}$ & \multicolumn{2}{|c|}{$£ 3,202,947$} \\
\hline Combined day and stay visitor expenditure & \multicolumn{2}{|c|}{$£ 3,519,195$} \\
\hline Economic impact, applying Skye multipliers: & & \\
\hline Additional local income $(=£ 3,519,195 \times 0.291)$ & \multicolumn{2}{|c|}{$£ 1,204,086$} \\
\hline $\begin{array}{l}\text { Additional full-time equivalent (FTE) jobs in Mull economy } 1992 \\
\text { ( } £ 28,374 \text { expenditure per FTE job) }\end{array}$ & \multicolumn{2}{|c|}{124} \\
\hline Additional FTE jobs in Scottish economy 1992 & & \\
\hline ( $£ 22,838$ expenditure per FTE job) & \multicolumn{2}{|c|}{154} \\
\hline
\end{tabular}


Hugh M. Begg,

Bob Henderson, Peter Tyler

and Colin Warnock

The impact of improved ferry

services on an island

economy: the case of Mull

World Transport Policy \&

Practice

2/ 4 [1996] 8-12
Even in an island economy such as Mull with a limited primary and manufacturing base, reductions in freight costs affected the cost of production for island producers. Given the type of the goods typically produced, island exporters were nearly always price takers or selling into niche markets. Thus reductions in production costs were not reflected in lower prices (for the former the price is set by the market, and for the latter there is a degree of monopoly power). Instead it fed into higher profits and, on occasion, higher wages. Higher profits were the more likely outcome and the increased viability of island businesses which resulted hel ped lead to increased output, employment and investment.

\section{Displacement effects}

We had established that changes in the quality of ferry services to Mull resulted in additional numbers of visitors to the island over and above the vol ume which would have visited if no improvements in the ferry services had taken place. As a result the local economy benefited from additional expenditure which would not otherwise have occur red. However, we were concer ned to establish whether this had been at the expense of other areas, i.e. whether the additional activity had been displaced from other parts of Scotland.

The displacement effect was consi der ed at different spatial levels: the impact on visitors spending in Scotland as a whole, the Highlands and Islands and in specific destinations within them. In order to provide an indication of the potential displacement effects within Scotland, visitors were asked whether they would have gone el sewhere if their trip had been frustrated by being unable to cross to $\mathrm{Mull}$ as a result of the constraints on the

Table IV

Potential displacement effects of improvement to Mull ferry services

\begin{tabular}{lcc}
\hline & $\begin{array}{c}\text { Visitor } \\
\text { spending } \\
(f)\end{array}$ & FTE jobs \\
\hline $\begin{array}{l}\text { Spending on Mull associated with ferry service } \\
\text { improvements }\end{array}$ & $3,519,195$ & 124 \\
$\begin{array}{l}\text { Non-displacing activity (33.6 per cent) } \\
\text { Potentially displacing activity (66.4 per cent) }\end{array}$ & $1,182,450$ & 42 \\
$\quad$ of which: & $2,336,745$ & 82 \\
$\quad$ Potential displacement from other Scottish islands & $1,280,536$ & 45 \\
$\quad \begin{array}{l}\text { Potential displacement from the Western Highlands } \\
\quad \text { (excluding other Scottish Islands) }\end{array}$ & 750,095 & 26 \\
$\quad \begin{array}{l}\text { Potential displacement from the rest of Scotland } \\
\quad \text { (excluding other Scottish Islands and the }\end{array}$ & & \\
Western Highlands) & 306,114 & 11 \\
\hline
\end{tabular}

provision of ferry services. The impact of the displacement effects at these different spatial level s can be estimated by applying the findings to the information set out in Table III which relates to the amount of additional expenditure and jobs generated on Mull as a result of the ferry enhancements. The results are set out in Table IV.

On the other hand we recognized that the fer ry enhancements may have involved some displacement of activity from Mull. I mproved access to the island for tourists is accompanied by easier access to the mainland for island residents. This can be expected to encourage some resi dents to make more frequent visits to the mainland for shopping or recreational activities and so reduce the proportion of household incomes spent on the island. By reducing remoteness, more islanders may be persuaded to remain who mi ght otherwise have emi grated. Additionally, incomers could be attracted to the island. We could not make any detailed forecast of these outcomes. However, in our view this "increased population" effect could, in the longer term, more than offset the "displaced expenditure" effect.

\section{Concluding remarks}

The methodology set out in this bri ef paper was devised to deal with a specific set of problems and our results are, of course, particular to the circumstances under consideration. However our case study required us to address a number of general issues to be found wherever ferry improvements for the benefit of island economies are under consideration. These include: the peaking of demand with substantial excess capacity at other periods; modelling the traffic movements consequent on the enhancement; establi shing the impact on the local economy; and, finally, the issues raised by displacement of traffic and economic activity. The approach which we adopted dealt effectively with these and related issues. We recommend its application to other similar situations.

\section{References}

Scottish Office (1993a), Evaluation of thel mpact of Ferry Subsidies, ESU Research Paper No. 32, Scottish Office Industry Department, Edinburgh.

Scottish Office (1993b), Scottish Tourism Multiplier Study, ESU Research Paper No. 31, Scottish Office Industry Department, Edinburgh.

Scottish Office (1994), Thel mpact of I mproved Ferry Services on Local Economic Development, ESU Research Paper No. 34, Scottish Office Industry Department, Edinburgh. 


\title{
A path out of the wilderness?
}

\author{
Angus W. Witherby \\ Lecturer in Transport Planning, Department of Geography and Planning, \\ University of New England, New South Wales, Australia
}

The discipline of transport planning is in conceptual disarray, yet the techniques and models of yesteryear continue to be applied. Argues that we need a new conceptual framework for deciding what methods to apply and how to apply them to produce liveable cities. Concludes that eco-relational thinking may offer a useful framework.
World Transport Policy \&

Practice

2/ 4 [1996] 13-19

(c) MCB University Press

[ISSN 1352-7614]

\section{Introduction}

This paper deals with the activity of transport planning. Transport planning is a specialized subset of the more general activity of urban and regional planning. However, while the land use si de of urban and regi onal planning has struggled, somewhat introspectively, with theories of planning, transport planning has paid significantly more attention to theories in planning. In large part this is a natural consequence of the di sci pline's strong intersection with engi neering. The rationalist, objective techniques that underlie the activity of transport planning as we have seen it devel op historically since the 1960s, are to do with the city as a machine. The implication is that it can be modelled, predicted, manipulated. It is also this inter section with engineering which gave transport planning a significantly more durable and clearly defined core of technique when compared to its cousin disci pline, land use planning.

\section{Technique}

Yet cl early we must face the reality that the objective/ rational body of technique developed over the last 30 years has and is failing us. Our cities are not improving in liveability as far as transport is concerned. This is despite an ever increasing plethora of techniques developed to analyse, predict and ultimately plan the transport networks of the city. In data collection we have household travel behaviour surveys, origin/ destination studies, traffic surveys and thelike; in demand analysis we have econometric models, heuristic models, simulation models and scenari o development; in supply analysis we have impact models and cost models; in decisi on making we have approaches such as the rational actor, satisficing, incrementalism, organizational process, political bargaining, decision-orientated planning process and more (Meyer and Miller, 1984). All this is before we even begin to deal with management techniques such as Transport Demand Management (Ewing, 1993).

\section{Conceptual disarray}

Dimitriou (1992) summed up the situation well when he described transport planning as being in "conceptual disarray". Whileconceptual disarray as a phenomenon could not be considered to have entered transport planning over night, Dimitri ou dates its dominance from the mid-1970s. In fact, the seeds were sown much earlier.

Buchanan's ground-breaking 1963 report clearly identified the essential tension faced by the discipline of transport planning in coming to grips with the ever-expanding use of the private motor vehicle. While most commentators, and in fact governments, focussed their attention on one aspect of Buchanan's thesis - that urban environments would need to be radically transfor med to cope with the car - less attention was paid to the other side of his thesis. Buchanan clearly acknowledged that limiting demand for the motor vehicle would be essential if we were to maintain the essential form and structure of urban areas as they had existed up to that time.

Weare now in 1996. A total of 20 years have elapsed since the start of the period that Dimitriou labelled conceptual disar ray. Yet in that time we have not seen any fundamental new paradigm for the discipline of transport planning that could help us re-focus the discipline's undoubted strengths on tackling the transport problems of urban areas in a manner that improves the liveability of the city. Instead, we have seen the evolution of a pastiche of techni ques, some rooted in the behavioural, some in traffic modelling, some in models of land use and transport interaction. Yet, returning to an earlier thesis, our approaches still attempt to treat the city as a machine. Even the behavioural approaches, which have arisen out of a clear recognition of the failure of transport planning to adequately predict results when focusing merely on vehicles, tends to fall into the deterministic trap.

At its worst, the cur rent situation can and does lead to feelings of entrapment and desperation on the part of the transport planning professi onal. We endlessly, almost mindlessly, continue to repeat the use of techniques that we know are flawed and which we suspect are not tackling the heart of our problem. Yet without the development of a coherent frame of reference within which to place those 
Angus W. Witherby

A path out of the wilderness?

World Transport Policy \&

Practice

2/ 4 [1996] 13-19 techniques, our planning processes are more fundamentally flawed than they need be.

\section{A new breed?}

Although resident activism has been a feature of transport planning debates for several decades, that activism has largely concer ned itself with what we now describe as the "nimby" syndrome - not in my backyard. In other words, the activism has not opposed the concept of (for example) a new freeway instead it has tended to oppose the location as affecting them.

Speaking from the Australian perspective, the first major signs of the shift in community activism came in Brisbane in the 1980s. A community group called Citizens Against Route 20 (CART) was for med in response to a proposal to widen an existing "rat run" into a major arterial route. Instead of lobbying to have the route put somewhere else, the group focussed its attention on the whole process of transport planning in the city of Brisbane, and, perforce, the role of the motor vehicle in soci ety. The group, drawing extensively on European experience, prepared a small volume entitled Traffic Calming (CART, 1989).

While it is certainly true that mainstream transport planning authors such as Brindle paid, and continue to pay, significant attenti on to the local area aspects of car/ people interaction, the CART publication attempted, somewhat falteringly, to place local needs in the bi g pi cture. It was an attempt, in the context of A rnstein's (1969) ladder of public participation, to develop genuine partnership between the community and the planners.

A founder of CART, David Engwicht, developed the thesis in his book Towards an E cocity - Calming the Traffic (1992). It was in that book that he used the ter m "eco-relational thinking".

\section{Eco-relational thinking}

Engwicht's "eco relational thinking" is used to cover a variety of issues surrounding the planning activity in general, the role of specialist, and more particularly applying these things to the examination of transport planning. At its core, eco-relational thinking is not a technique nor a philosophy. Instead it represents more of an attitude.

\section{A change of attitude?}

Is the answer to transport planning's cur rent conceptual problems as si mple as a change of attitude? The answer, as with all such questions, is both yes and no. On the "yes" si de, it is difficult to dispute Engwicht's thesis that, if soci ety as a whole and transport planners in particular changed their atti tude to the role of the motor car in society, then we could certainly improve the liveability of our cities. The "no" part of the question comes down to the difficulty and complexities (not to mention some interesting moral questions) involved in changing the attitudes of an entire society.

Yet Engwi cht provides examples of aspects of living where this has been done. He quotes the example of smoking (Cunningham et al., 1994). Until the 1980s the dominant paradigm on smoking was that it was an activity of unconstrained free choi ce by adults. Yet as the health implications of smoking became more widely known, especially those of passive smoking, gover nments through a combinati on of regulation and education, backed by a number of other medical and community groups and organizations, achi eved a soci etal shift in views on smoking. The odd person out in Australia today, in any particular group of people, is likely to be the one with the cigarette - not those wi thout.

Engwicht sees the possibility of achieving a si milar shift in public atti tude to the use of the motor vehicle. It almost goes without saying that he sees such a shift in attitude as a necessary precursor to transport planning gaining the ability to improve substantially the liveability of our cities. Engwicht is not alone in perceiving these shifts. Authors such as Nijkamp and Rei chman (1987) identify clear shifts away from satisfying endless growth in car-based mobility, albeit from a European perspective.

In many respects, the atti tudinal change that Engwicht is seeking is one that is contrary to the prevailing ethos of our time- one of increasing privatization and individualization - which some consi der to be leading to the fragmentation of our culture (Cunningham, 1996). It is also contrary to the "reductionist thinking" identified by Giannakodakis (1994) as under pinning our current approach to transport planning. Can we return, asks Cunningham (1996), to the city as the highest pi nnacle of human achi evement where the public and cultural aspects of human nature can make their highest contribution to human quality of life?

The nature of the city

Ultimately the city is all about human exchange - not just of goods and money, but of thoughts, ideals, emotions, indeed all facets of human behaviour. In A ristotlean terms, the city is the fundamental basis of "the good life". By focussing on transport as an end in itself, we have lost sight of the fact that it is merely a means to the end of exchange. We have, unfor tunately, assumed that mobility 
Angus W. Witherby

A path out of the wilderness?

World Transport Policy \&

Practice

2/ 4 [1996] 13-19 equals exchange oppor tunity. Ther efore, all we have to do is enhance societal mobility, primarily through the private car, and everybody will have a happy and fulfilling life.

The big picture

It is the "big picture" of the city and its purpose which lies at the heart of the concept of eco-relational thinking - to exami ne the city holistically in the context of the complex web of inter-relationships that give it its form and function. It is important, however, not to confuse holistic thinking with only thinking about the city at a macro scale. Holistic thinking can also be applied at a variety of scales when examining the city from metropolitan right down to nei ghbourhood, street or even househol d scales (Giannakodakis, 1994). We see glimmers of holistic thinking in the behavioural approaches to transport analysis that have been under development for the past decade or so. Techniques such as the household and travel survey (HATS) clearly attempt to get a handle on the complex interrelationships of travel and behaviour of a househol d; Fisk (1986) attempts to deal holistically with both supply and demand; Florian et al.'s (1988) si tuation planning paradigm clearly recognizes the impor tance of a broad perspective in dealing with particular transport problems, to quote just a few.

Never thel ess, while these techni ques are groping forward towards the eco-relational concept, they miss one vital point. They are still focussed on transport the activity. The problem with this approach is that transport is a derived demand. With virtually no exceptions, transport activity is under taken as an enabling activity to allow people to do something else. It is that "something else" that should be thereal focus of the planner's concer $\mathrm{n}$.

The role of the professional

Transport planners are mobility specialists. This is what we are good at. We are not, however, as good at dealing with the question of why the mobility is necessary, the other side of the mobility coin: accessibility. The increase in mobility in our society blocks, and continues to block, accessibility to many basic servi ces and functions for many people (Manning, 1978). How could this problem occur? Part of the answer lies in professionalism.

Professionalism is increasingly about specialization. No one individual, for instance, can grasp even the detail of a single specialization in our society. Looking to our own field of transport planning, a thorough grasp of even the major techniques currently used in the discipline would be beyond all but a few. Engwicht sees the present special izati on of the professions as symptomatic, and an evolution, of the compartmentalization of thinking that has developed in wester n society throughout the last several hundred years. Engwicht maintains that in the rise of the scientific method and its pervasion of all aspects of our society, we have lost "the big picture".

The role of the generalist

Engwight does not advocate abolition of the special ist. Rather, he sees the rol e of the specialist as informing the generalist. But who is the general ist? It has been stated that every person is an expert - even if it is only on their own backyard. By the same token, every person is, at least potentially, a generalist. Yet in looking at the role of the generalist, we need to go beyond the mere accumulation of general knowledge that the average individual collects during the course of their life about their society and how it works. At the other end of the spectrum, we do not need a moder n version (male or female) of "renaissance man". Instead, we need people with the skills to integrate and translate. The "professi onal generalist", as such a person might be ter med, has the role of bringing the in put of specialists to bear on the particular problem of liveability in cities.

This, in Engwight's conception, can only be done by such a person not only immersing themselves in the problem from an intellectual sense, but also by engaging themselves in living with and in the problem. Thus the professional generalist acts as the bridge for the inter section of the hopes, desires, fears and aspirations of communities within the city, and theskills, expertise and experience of specialists who have some of the tools to address those problems.

This approach can be vi ewed along with the strategic planning and perfor mance systems framework of Giannakodakis (1994), an example of which is shown in Figure 1. Yet despite the different perspectives from which these two authors vi ew the problem, their views are complementary rather than divergent. Immersion in a problem is necessary, but humans are structure-needing beings who need frameworks on which to hang the product of their work.

The Engwi cht approach also inter sects neatly with the conceptual framework developed by Brindle and others, known as the Darwin Matrix (Tablel). This matrix attempts to explore the range of measures avai lable to implement what is now known as traffic calming. It probably al so has wider application and could be used to encapsulate the major aspects of transport planning. In 
Angus W. Witherby

A path out of the wilderness?

World Transport Policy \&

Practice

2/ 4 [1996] 13-19

\section{$\overline{\text { Figure } 1}$}

A systems entity model of the road transport system

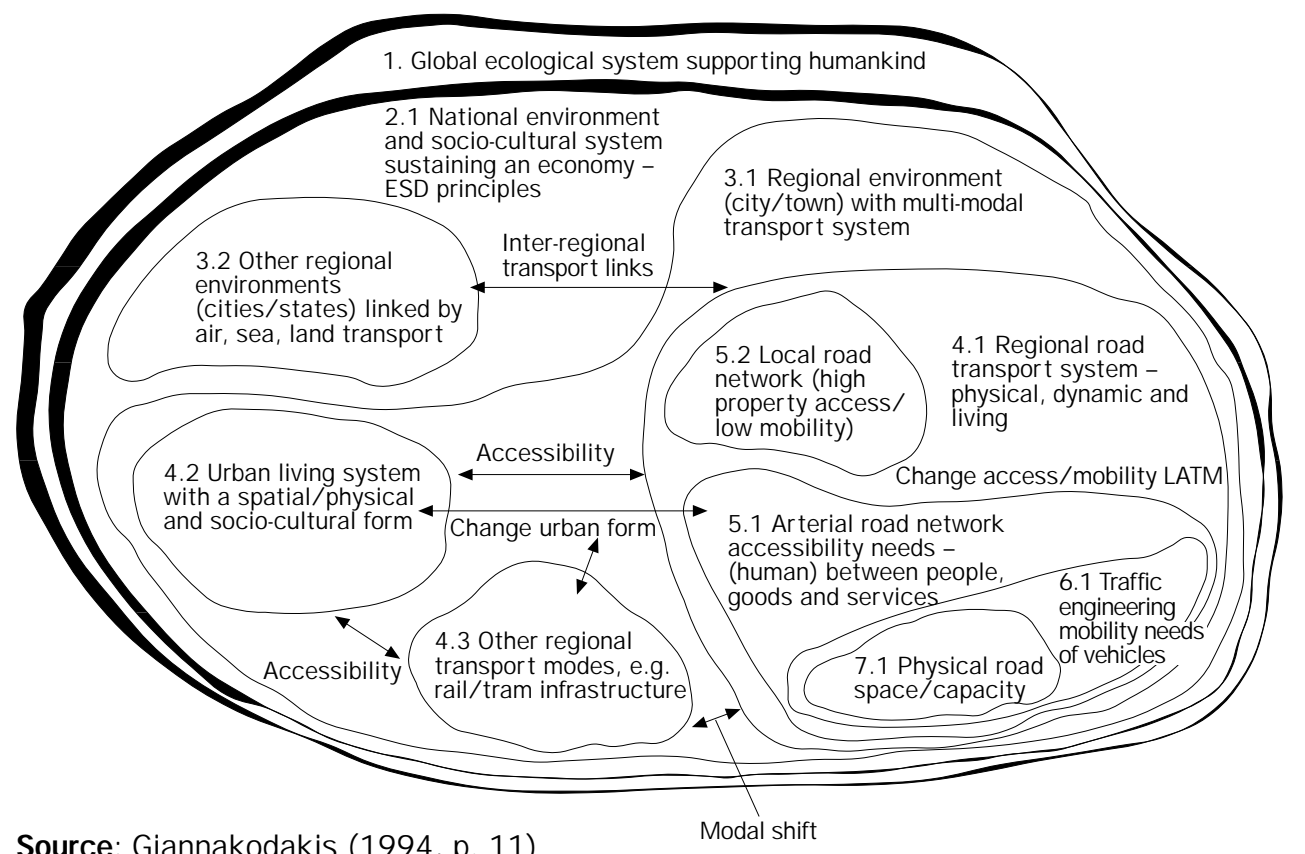

Source: Giannakodakis (1994, p. 11)

$\overline{\text { Table I }}$

The Darwin Matrix

\begin{tabular}{|c|c|c|}
\hline \multirow[t]{2}{*}{ Scope of measure } & \multicolumn{2}{|c|}{ Type of measure } \\
\hline & $\begin{array}{l}\text { Physical/ environmental ("technique") } \\
\text { (includes all physical and management } \\
\text { measures to control level, route and } \\
\text { speed of traffic) }\end{array}$ & $\begin{array}{l}\text { Social cultural ("ethos") } \\
\text { (includes both deliberate attempts to } \\
\text { change community attitudes and other } \\
\text { societal changes that may not be direc } \\
\text { related to traffic matters and that may } \\
\text { not be either deliberate or voluntary) }\end{array}$ \\
\hline $\begin{array}{l}\text { Local } \\
\text { (street or neighbourhood) }\end{array}$ & $\begin{array}{l}\text { Level I traffic calming techniques } \\
\text { (e.g. speed control devices; "green } \\
\text { street") }\end{array}$ & $\begin{array}{l}\text { Level I social change (e.g. neighbourho } \\
\text { speed watch; attitudinal change) }\end{array}$ \\
\hline $\begin{array}{l}\text { Intermediate } \\
\text { (zone, traffic corridor, } \\
\text { regional road) }\end{array}$ & $\begin{array}{l}\text { Level II traffic calming techniques } \\
\text { (e.g. sub-arterial traffic management } \\
\text { (SATM) parking policies, pedestrianized } \\
\text { shopping areas) }\end{array}$ & $\begin{array}{l}\text { Level II social change (e.g. voluntary } \\
\text { behaviour/ mode choice change) }\end{array}$ \\
\hline City-wide & $\begin{array}{l}\text { Level III traffic calming techniques } \\
\text { (e.g. urban form manipulation, total } \\
\text { system measures/ policies) }\end{array}$ & $\begin{array}{l}\text { Level III social change (e.g. cultural } \\
\text { change, loss of choice, technological } \\
\text { change) }\end{array}$ \\
\hline
\end{tabular}

many respects it represents a simpler (reductionist?) view of Giannakodaki s's (1994) system model. Effectively what Engwicht is suggesting, is that transport planning needs to pay much more attention to social/cultural measures (the "ethos" of what we are doing) and use this to inform the "technique" of the profession. Giannakodakis attempts to provide a framework that could be used for systematic action within the matrix.

\section{Implementation}

It is all very well to talk about attitudinal change, but how in practice can we translate this changed attitude into practical planning outcomes? This will be addressed through the examination of two small-scale case studies. The first of these attempted to implement ecorelational principles as part of a broad-based strategic planning effort. The second was a 
Angus W. Witherby

A path out of the wilderness?

World Transport Policy \&

Practice

2/ 4 [1996] 13-19 "traditional" traffic study designed to address the long-ter $m$ structural needs of a growing area. Both of the case studies had as their output clear recommendations regarding the devel opment of transport infrastructure to serve the needs of the area. These recommendations were, however, ar rived at by completely different routes.

The Armidale/ Dumaresq Strategic Plan (after Witherby, 1994)

The Armidale/ Dumaresq Strategic Plan arose out of a perceived need to provide for urban growth around the small rural city of Armidale, NSW. Ar midale is an inland city with a populati on catchment of around 30,000 people. There was a perceived shortage of residential land to meet the needs of the city, and concer $n$ was being expressed about the social, environmental and transport implications of growth. Although commencing as a somewhat traditional land use planning exercise, the strategy soon evolved into a broader strategic consideration of the region's future. In particular, it became clear that the Armidale/ Dumaresq community had and was capable of articulating a range of views regarding its vision of the region's future. Through a series of consultation processes similar to those espoused by Engwicht, the strategy was able to not only gather the views of the community, but also, with the community, devel op them into an over-arching vision within which the majority of the community's aspirations could be pursued. The vision emerging was clearly a "quality of life" vision. Integral to this vision was seen the need to come to grips with the implications of the motor vehicle on quality of life.

It must be stated at the outset that in conventional transport planning ter ms, Armidale does not have a traffic problem. Nevertheless, it was clearly seen that in ter ms of improving the quality of urban space within the city, the balance between the car and other road uses needed to be redressed. The outcome of the process was a clear set of recommendations regarding transport in the city. It should be noted that these were developed in the clear (and deliber ate) absence of the use of traditional traffic modelling or forecasting tools. Those conclusions, together with their place in the Darwin Matrix were (Wither by, 1994, p. 323):

1 Pedestrianize the central business district (CBD) completely, while ensuring adequate peripheral parking, disabled car access and alter native "clean" transport from the peri pheral parking areas through the CBD area (local scope, level I, II and to an extent III physical/environmental changes, level I and II social/ cultural change).

2 Consider the implementation of a local gover nment-based "community service obligation" payment to the local bus operator to assist their proactive efforts to improve mode split towards public transport (city-wi descope, level III physical/ environmental changes, level II social/cultural change).

3 Develop a transport plan for the University of New England to reduce car dependence by people travelling to this single largest employment node in the city. Aspects such as improved public transport, car pooling, reducing parking availability on campus and further encouragement and provision of faciliti es for cycling are under review (inter mediate scope, level I and II physical/ environmental changes, level I and II social/ cultural change).

4 Programme, over a 20- to 30-year period, the reconstruction of the complete road system of city of Armidale under Local Area Traffic M anagement principles. This reconstruction would occur as and when roads fell due for reconstruction in the normal course of events and would produce design speeds of $40 \mathrm{kph}$ on the "arterial" and collector roads and design speeds of $20 \mathrm{kph}$ on resi dential access streets (citywide scope, level I, II and III physical/ environmental changes, level I, II and to an extent III social/ cultural change).

5 Maintain the current land use pattern of the concentrated CBD core and encourage further development in medium density housing in and near the CBD area. In addi tion devel op measures that assi st the retention of the corner store network throughout the city (city-wide scope, level III physical/environmental change, level II and III social/ cultural change).

6 All new subdivision areas be constructed on integrated, multi-mode principles from day one with those areas more remote from the city being connected by denied assess collectors as well as cycling, walking and public transport routes (local scope, level I physical/environmental change, level I social/ cultural change).

Probably the key aspect of the A rmidale case study is that it deals with the problem of bringing about physical and social change through the simultaneous application of changes on both fronts in a variety of ways. It seeks not revolution, but evolution.

\section{Coffs Harbour}

The Coffs Harbour exercise was somewhat different. Coffs Harbour is a rapidly growing 
Angus W. Witherby A path out of the wilderness? World Transport Policy $\&$ Practice

2/ 4 [1996] 13-19 coastal NSW town with a regional population of approximately 50,000 people. It is also a popular tourist destination. The high growth rate, coupled with previous under-investment in transport infrastructure, has produced a situation where there is a perceived need for substantial upgrading and expansion of the road network. In traditional transport planning fashion, a traffic study was commissioned from a mainstream transport engineering firm. Setting asi de some qui bbles with the methodology, it is useful to focus on the key assumptions underlying the study. Of major importance were the linear projection of traffic growth as population and economic activity rise, and the assumption of increased trip-making propensity by the residents of the area. Naturally enough, the study recommended widening of the main north-south highway through the region and the development of a "traffic relief route" to bypass the major commercial centre.

Many residents in the Coffs Harbour area challenge the need to upgrade substantially road infrastructure. They point to the significant sever ance and traffic noise and safety implications of constructing a traffic relief route along the proposed cor ridor, which bisects a major tourist residential area. They note that during the peak holiday period, Coffs Harbour (which is a significant resort destination) appears to function qui te adequately with nearly a doubling of its population.

These resi dent views suggest that the style of exercise carried out in A rmi dale may be appropriate. Perhaps an attempt needs to be made to place transport within its context as an enabler of the various activities of the city, and to address seriously the degree to which mobility enhancement via the private car will fur ther that function. Certainly it is clear to many "non-experts" in Coffs Harbour that traditional transport planning has failed them.

\section{Conclusions}

While the above outcomes demonstrate that Engwicht's princi ples are capable of operation and appear to have benefit when applied on a small scale, the questi on is still open as to whether these principles can be applied at the metropolitan level. For example, there has been increasing discussion about what are becoming known as "urban villages" as a "solution" to urban liveability. Cunningham et al . (1994) proposed a framework within which substantial shifts in the need for mobility could be achieved, thereby reducing car dependence, yet maintaining a good level of access to "exchange oppor tunities". A si milar framework has been proposed by Newman and Kenworthy (1992) with their transit oriented urban villages.

Yet intrinsic within the viability of these frameworks is the need to modify substantially mobility patterns within the city. Simply providing local opportunities for shopping, work and leisure may not necessarily impact on mobility - people with access to private cars will freely travel out of their urban village unless atti tudes to, and restrictions on travel change significantly (Manning, 1978). A nother difficulty is that people appear to have a travel time "budget" which they are willing to use in whatever way technology will let them and they can afford. A good example is the average jour ney to work time, which has not varied significantly in Sydney in the last century. A final (and more significant) problem is that we are not seeing evidence of these types of approaches being developed from the "ground up" using Engwicht's principles of understanding of the city and full partnership with its people. Neither can we be confident that they are "solutions" that really operate within the full scope of Giannakodakis's systems framework.

The conclusions that we can draw from this are that planning solely at the local scale, while complex enough, is unlikely to solve metropolitan scale problems unl ess quite substantial shifts in attitude occur at a societal, rather than just a community level. Even then, and even at the local level, change towards the bottom right of the Darwin Matrix is morelikely to occur by evolution rather than revolution (Witherby, 1994). It is also clear that we cannot solely address the problems of the city at the macro scale. If we do (and as we have), the hopes, fears, aspirations and concerns of local communities are unlikely to be truly addressed.

This is not to say that substantial improvement to theliveability of our major cities cannot be achieved. There is much that can be done and is being done to address major problems and issues. Many of these are "whole city" strategic initiatives; many of these are local initiatives. The two need to be given equal recognition, and the impacts of one on the other addressed in true partnership with the communities affected. There are some signs that we are now entering a period of relative stability after the rapid change of the post-war era (Deen, 1984). This will assist in providing an environment more condusive to the planning task, provided we have an appropriate frame of reference for that task.

What is also becoming apparent is that, even with changed attitudes, and a more 
Angus W. Witherby

A path out of the wilderness?

World Transport Policy \&

Practice

2/ 4 [1996] 13-19 stable framework, these problems cannot be solved by planners (whether transport or land use) alone. Changing the framework, and our attitudes to the task, of our profession is, however, an essential start, and one which can give us an effective directi on for the future.

\section{References}

Arnstein, S. (1969), “A ladder of citizen participation", AIP J ournal, J uly, pp. 216-24.

Brindle et al., Citizens against route 20 (CART) (1989), Traffic Calming, CART, A shgrove, Queensland.

Cunningham, C. (1996), "A philosophical framework for urban planning: the concept of altruistic surplus", in van der Meulen, G.G. and Erkelens, P.A. (Eds), Urban Habitat: The Environment of Tomorrow, Eindhoven University of Technology, Delft, 16February, pp. 86-96.

Cunningham, C., Engwicht, D. and Witherby, A. (1994), "Islands in the sun", Talking to New England, ABC Radio, broadcast $14 \mathrm{M}$ arch.

Deen, T.B. (1984), “Transport planning - when are things going to get better?" ITE J ournal, Vol. 54, August, pp. 18-22.

Dimitriou, H. (1992), Urban Transport Planning A Developmental A pproach, Routledge, New York, NY.

Engwicht, D. (1992), Towards an Eco-city - Calming theT raffic, Envirobooks, Sydney.
Ewing, R. (1993), “TDM, growth management and the other four out of five trips", Transportation Quarterly, Vol. 47 No. 3, pp. 343-66.

Fisk, C. (1986), "A conceptual framework for optimal transportation systems planning with integrated supply and demand models", Transportation Science, Vol. 20 No. 1, pp. 37-47.

Florian, M., Gaudry, M. and Lardinois, C. (1988), "A two dimensional framework for the understanding of transportation planning models", Transport Research, Vol. 22B No. 6, pp. 411-19.

Giannakodakis, G. (1994), “Transport planning: a hol istic systems approach", Road and Transport Research, Vol. 3 No. 3, September, pp. 4-21.

Manning, I. (1978), TheJ ourney to Work, George Allen and Unwin, Sydney.

Meyer, M. and Miller, E. (1984), Urban Transportation Planning, McGraw-Hill, New York, NY.

Newman, P. and Kenworthy, J . (1992), "Transit oriented urban villages: design solution for the 90s", Urban Futures, Vol. 2 No. 1, pp. 50-58.

Nijkamp, P. and Reichman, S. (Eds) (1987), Transportation Planning in a Changing World, Gower, VT.

Witherby, A. (1994), "Traffic calming a city", Papers of theAustralasian Transport Research Forum, Vol. 19, Transport Research Centre, University of Melbourne.

WSROC (1993), Towards Traffic Calming: A Manual of Implemented Experience, Report no. CR 126, Federal Office of Road Safety and the Western Sydney Regi onal Organisation of Councils, Canberra. 


\title{
Placebo or panacea? Rural transport corridors: some social and environmental issues
}

\author{
Amanda Root, William J. Fielding \\ Transport Researchers, Environmental Change Unit, University of Oxford, UK
}

Travel poverty, defined as

"inadequate access to choice in relation to travel", is faced by those who cannot travel as much as they would like, or who have inadequate local amenities, reducing options about travel. The context for this study is increasing rural car use and by policies which directly or indirectly promote it, damaging the quality of life and the environment and lessening the safety of public space. Presents evidence from a study of two rural villages indicating that the development of public transport corridors might, in some circumstances and to some extent, meet sustainability (i.e. environmental, equity and participation) objectives. Also discusses possible limits to the effectiveness and potential disadvantages of developing rural public transport corridors. Raises the particular effectiveness of rail corridors in meeting environmental objectives.

World Transport Policy \&

Practice

2/ 4 [1996] 20-27

(c) MCB University Press

[ISSN 1352-7614]

\section{Rural travel and its problems}

Increases in miles travelled per capita is a worldwide trend, but one that is more pronounced in developed countries. Between 1989-93 there was a 9 per cent growth in distance travelled in Oxfordshire (Oxfordshire County Council, 1994). The County exempli fies the upward travel trends which are found in Europe and across the developed world (Greene and Santini, 1993).

In Europe, thereare clear correlations between income and travel, with a trend that increased affluence contributes to greater demand for travel (Stanner and Bourdeau, 1995). Currently, there are also spatial differences in UK travel demand. Rural dwellers travel further in total than urban residents (Table I). Rural people are travelling 49 per cent further than their urban counter parts, 70 per cent further as car drivers and 66 per cent more in cars as drivers and passengers. Rural peoplearealso less likely to use public transport or walk than urban residents. This is ironic when it is consi dered that the ster eotype of life in the countryside is that it is "settled" and "rooted" and not as mobileas urban life.

Car travel is exceeding other modes of transport by a ratio of almost 8:1 in rural areas (Table I), but this was not always the case. It has been argued that the UK policy of closing railways in the 1960 s and supplying a substitute bus ("bustition") contributed to the growth in private car ownership:

Theso-called "bustitution" policy has proved wholly ill-founded, for where the railways had proved more than capable of competing with the private car, buses had failed. Indeed rai Iways closures had actually forced many people to buy their own transport, precipitating the near collapse of rural public transport (Henshaw, 1994).

The loss of rural public transport, referred to earlier, has been exacer bated by the 1985 Transport Act, which deregulated buses, enabling many bus companies to choose more profitable, often urban, routes and to withdraw more remote or less well-used rural services.

The rise in the use of private cars has contributed to the loss of local facilities, particularly in rural areas. Cars allow access to non-local amenities for those with their own transport, but have facilitated a spate of centralization of public and private sector facilities. Peripatetic health services, which were common place in small $(<1,000)$ Oxfordshire villages until the 1960s, are now a rarity. It would appear that rural travel poverty, defined as inadequate choice in relation to travel, has grown as local facilities and public transport have decli ned.

Those without access to cars, are frequently travel poor, especially in remote rural areas, where public transport and local facilities are often negligible. Of households in rural England and Wales, 21 per cent do not own a car (ACRE, 1994). It should also be noted that a much larger percentage of people do not have access to a car during the day, often because the main household car is being used by a wage earner, or they do not have a driving licence or they are too young or disabled to drive. In rural areas a large number of households (estimated to be approximately 11 per cent of therural population) run a car and are unable to afford "necessities" as a consequence.

There are al so a large number of disadvantages of increasing reliance on the private car. As many authors have described, climate change and an increase of morbidity and mor tali ty are attributable to vehicle emissions. Transport accounts for approximately 30 per cent of personal energy use and the proportion is increasing.

\section{Transport corridors}

Public transport corridors are defined as particular routes along which there is a concentration of bus, train or other forms of public transport. In this study, the public transport corridor included buses and trains. They could be based on guided buses, community buses, new railway lines, trams or even cycle lanes.

Developing public transport corridors would involve allowing more housing or light industrial development at the "nodes" or public transport corridors and so, potentially, providing larger numbers of passengers, 


\begin{tabular}{|c|c|c|c|}
\hline \multirow{3}{*}{$\begin{array}{l}\text { Amanda Root and } \\
\text { William J. Fielding } \\
\text { Placebo or panacea? } \\
\text { Rural transport corridors: } \\
\text { some social and } \\
\text { environmental issues }\end{array}$} & \multicolumn{3}{|c|}{$\begin{array}{l}\text { Table I } \\
\text { Average number of miles per person per year by } \\
\text { mode of transport }\end{array}$} \\
\hline & Type of settlement & Rural & Urban \\
\hline & Car driver & 4,890 & 2,881 \\
\hline \multirow{8}{*}{$\begin{array}{l}\text { World Transport Policy \& } \\
\text { Practice } \\
2 / 4 \text { [1996] 20-27 }\end{array}$} & Car passenger & 3,046 & 1,878 \\
\hline & Other private & 355 & 218 \\
\hline & Rail & 311 & 429 \\
\hline & Local bus & 194 & 285 \\
\hline & Other public & 186 & 207 \\
\hline & Walk (over one mile) & 157 & 247 \\
\hline & All modes & 9,140 & 6,145 \\
\hline & \multicolumn{3}{|l|}{ Source: Stokes (1995) } \\
\hline
\end{tabular}

which might gener ate more frequent services, easier and faster modal changes and greater numbers of destinations.

Some transport cor ridors have been successfully developed. Copenhagen, for example, has fostered a "hand print" shape in which the "fingers" are transport corridors. The European Union is also developing a Trans-E uropean Network (TENs) which is intended to provide public transport and road corridors, mainly for inter-urban freight journeys. It was our intention to investigate the usefulness of rural public transport corridors for passengers, on a much smaller scale.

\section{Methodology}

Two villages in South Oxfordshire (the outer South East region of the UK) were surveyed in the summer of 1995. Infor mation was gathered from Chalgrove, which has limited bus services; and Cholsey, which has good bus and train services (Figure 1 ).

A total of 279 people completed questionnaires, which included a travel diary of single day jour neys. A total of 1,692 individual journeys were analysed. All the travel diaries have been put onto a database: 279 people filled in travel diaries and questionnaires. Infor mation was gathered fairly evenly from both villages: from Chalgrove 145 people (52 per cent of the sample), and from Cholsey 134 people (48 per cent of the sample) returned and completed questionnaires (see Table II).

The survey methodology involved a team of interviewers visi ting households i dentified by the Census, and sometimes by local contacts, as likely to have resi dents in the 16-29 age group. If the househol d did contain a 16-29 year old and if those concer ned were willing, each person was left a form which consisted of a day's travel diary and a questionnaire.

The questionnaire methodology was supplemented by various focus group interviews and unstructured interviews. In a cultural analysis it is possible to find "structures of feeling" or "cultural forms" that often play a more important and per manent part of everyday life than any particular set of opinions or views. It is hoped that the brief introduction of cultural analysis helps to lose some of the difficulties inherent in attitudinal surveys where answers may appear inconsistent or superficial (often owing to the context-dependence of the questions remaining unanalysed).

A total of 7616-29year olds were interviewed in groups in Oxfordshire. No statistical data were collected, but the intervi ews were recorded and have been transcribed. One of these interviews is quoted in this article.

Background information about the villages

Cholsey and Chalgrove were chosen because they are similar in size and demographic profile. Cholsey is approximately one-fifth larger than Chalgrove (the villages are 2,832 and 3,428 respectively). No two villages are identical, but there are strong si milarities

Table II

Sample by age group

\begin{tabular}{lcccccc}
\hline \multicolumn{7}{c}{ Age } \\
Village & Under 12 & $12-15$ & $16-29$ & $30-59$ & $60+$ & Total \\
\hline Chalgrove $^{a}$ & 1 & 7 & 50 & 82 & 3 & 143 \\
Cholsey $^{2}$ & 4 & 20 & 38 & 69 & 3 & 134 \\
Note: ${ }^{\text {T}}$ Two missing cases from Chalgrove \\
\hline
\end{tabular}


Amanda Root and

William J. Fielding

Placebo or panacea?

Rural transport corridors:

some social and

environmental issues

World Transport Policy \&

Practice

2/ 4 [1996] 20-27 between these two villages. House prices (compared in J anuary 1996 from a sample of 45) after all owing for number of bedrooms and house design, were broadly the same ( $£ 96,000$ and $£ 100,700$ respectively).

The effect of transport corridors The residents of Chalgrove travel to more diverse destinations than the residents of Cholsey. Figure 2 shows the jour neys from Chalgrove, which arealmost in the shape of a star and Figure 3shows jour neys from Cholsey, in which there are three main axis of pathways from the village.

In Figures 2 and 3 the lines have been weighted by volume of jour neys to the main destinations. The figures relate to total of journeys - by any mode, not just public transport. J our neys within the same village, town or city and jour neys between and from nonOxfordshire destinations into Oxfordshire have been omitted.

Public transport avai lability may funnel travel demand into corridors. The availability of good public transport, i.e. at least an hourly service, contributes to over half of all trips going to destinations along its routes (Figures 2 and 3 ).

\section{$\overline{\text { Figure } 2}$}

J ourneys made by the residents of Chalgrove

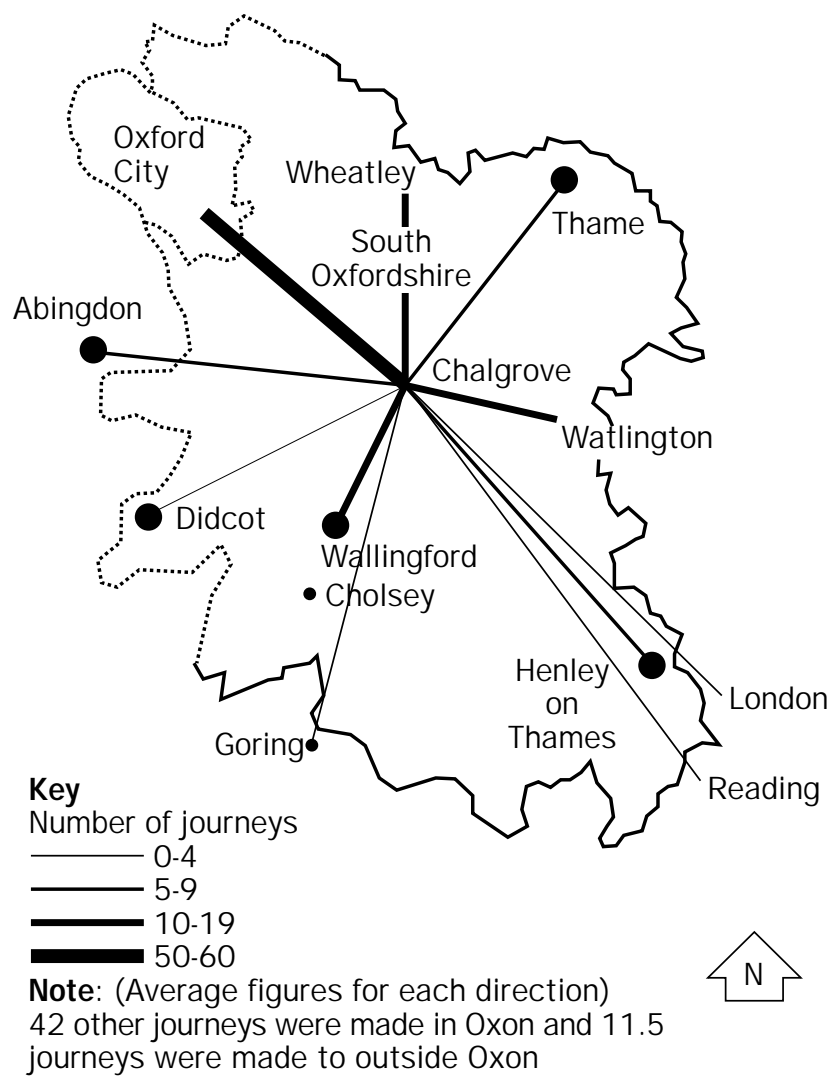

Do public transport corridors diminish travel poverty?

Travel poverty is related, we believe, to lack of choice. From the questions of mode of travel used for each journey and the availabi Iity of a car, it has been possible to ascertain some infor mation on choice.

In Tables III and IV, the numbers indicate the proportion of journeys in which a car was available as an alter native, ranging from no choice for bus users ( 0 per cent) to complete choice of car mode for motorcycleand taxi users (100 per cent). There is a 97 per cent level of choice for car users as some of them were being given lifts, and they did not havea car available to use on a different journey.

Tables III and IV show that a higher proportion of those travelling by bus and train in Cholsey had a choice ( 37 per cent and 92 per cent respectively) of using a car compared with those in Chalgrove (0 per cent has a choice in relation to the bus, there was no train use recorded by residents in the sample). This indicates that the higher level of public transport provision in Cholsey increases modal choice and discourages car use.

However, more of those cycling had a choice in Chalgrove than in Cholsey. This figure may reflect the higher levels of car ownership in Chalgrove compared to Cholsey.

There is clearly a greater proportion of people making a choice not to use a car in Cholsey. (The weather was not a factor as this survey was undertaken during a heatwave in August, when there was no rain.) A part from taxis, the trains have the ability to attract the highest proportion of those who could use a car. J ourney desti nations from Cholsey have al ready been shown to be concentrated along the routes served by the train (Figure 3 ). This indicates potential for encouraging modal switching to the train, given more appropriate costs and services.

In ter ms of increasing choice, then, this public transport corridor, along with good local facilities (in this case a market town about 4 mi les away) succeeds. However, it is not clear that those who were able to exercise the choices were those who would otherwise be unable to travel. Much of the most telling data which we collected to answer this question were qualitative, as the issues were often complex and dynamic, and could not be easily be captured with, in this instance, the somewhat blunt instrument of a questionnaire. 
Amanda Root and

William J. Fielding

Placebo or panacea?

Rural transport corridors:

some social and

environmental issues

World Transport Policy \&

Practice

2/ 4 [1996] 20-27

\section{The travel poor}

In both villages, those on state benefit, unskilled manual workers and housewives are making, on aver age, much shorter journeys than people in other social groups (Figures 4 and 5). People on state benefit and housewives would belikely to spend much of their time at home, and, possibly, unskilled manual workers might work more locally than people with other skills. This could indicate travel poverty. Typically, these groups are amongst the low-paid, and lack of disposable income is often correlated to not being able to travel as much as is wanted.

In answer to the question "Has there ever been a job you consi dered, but didn't apply for because of the difficulties of getting there?" 33 per cent of those who answered (37) said yes. This answer raises issues about the economic inefficiency of not having more adequate public transport infr astructure or land-use policies.

However, this figure may be inflated by the large number of young people in this survey, many of whom may be students or in the early stages of their working lives, and so $\overline{\text { Table III }}$

Choice in travel mode for journeys starting in Chalgrove

\begin{tabular}{lcc}
\hline $\begin{array}{l}\text { Mode of } \\
\text { transport }\end{array}$ & $\begin{array}{c}\text { Proportion who } \\
\text { had a choice (\%) }\end{array}$ & $\begin{array}{l}\text { Number of } \\
\text { journeys }\end{array}$ \\
\hline Bicycle & 33 & 33 \\
Bus & 0 & 39 \\
Car & 97 & 405 \\
Motorcycle & 100 & 7 \\
Taxi & 100 & 2 \\
Walk & 75 & 275 \\
\hline
\end{tabular}

$\overline{\text { Table IV }}$

Choice in travel mode for journeys starting in Cholsey

\begin{tabular}{lcc}
\hline $\begin{array}{l}\text { Mode of } \\
\text { transport }\end{array}$ & $\begin{array}{l}\text { Proportion who } \\
\text { had a choice (\%) }\end{array}$ & $\begin{array}{l}\text { Number of } \\
\text { journeys }\end{array}$ \\
\hline Bicycle & 16 & 79 \\
Bus & 37 & 35 \\
Car & 97 & 406 \\
Taxi & 100 & 3 \\
Train & 92 & 37 \\
Walk & 91 & 243 \\
\hline
\end{tabular}

unlikely to be earning aver age wages. Low income could then be cor related with a lack of mobility due to not being able to afford driving lessons or a car.

The foll owing comment illustr ates some of the strong feelings about lack of travel opportuniti es from a group of young people in one of the villages studied. The boys perceive that lack of faciliti es leads them to crime:

Spike: We need transport or we need faciliti es. Or all we do is get in trouble. True or false?

[Clamour of voices]

AR: How do you think transport would help?

Spike: Get us out of trouble, won't it? We'd be doing things. We might get pissed an' that, but..

Andy: What's stopping you going to Oxford and beating someone up? That [transport] ain't going to keep you out of trouble is it? Spike: Yeah! (emphatically) But what's stopping us here... smoking drugs and that? If we went to Oxford...

Andy: There's nothing stopping you smoking drugs, man...

Spi ke: Yeah, but if we'd got transport you're going to be doing other things ain't you?

Spike felt that the absence of good transport and faciliti es lead to anti-social behaviour (e.g. the desire to get into fights) and better transport would encourage more socially acceptable activities through wider 
Amanda Root and

William J. Fielding

Placebo or panacea?

Rural transport corridors:

some social and

environmental issues

World Transport Policy \&

Practice

2/ 4 [1996] 20-27

$\overline{\text { Figure } 4}$

Median distance travelled on study day by occupation for the residents of Chalgrove

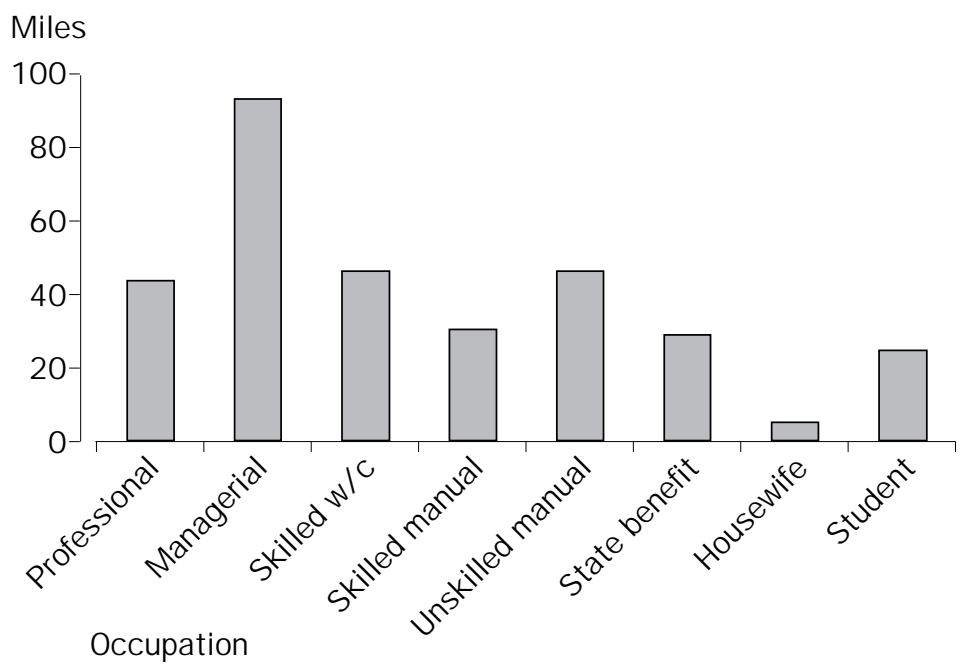

$\overline{\text { Figure } 5}$

Median distance travelled on study day by occupation by the residents of Cholsey

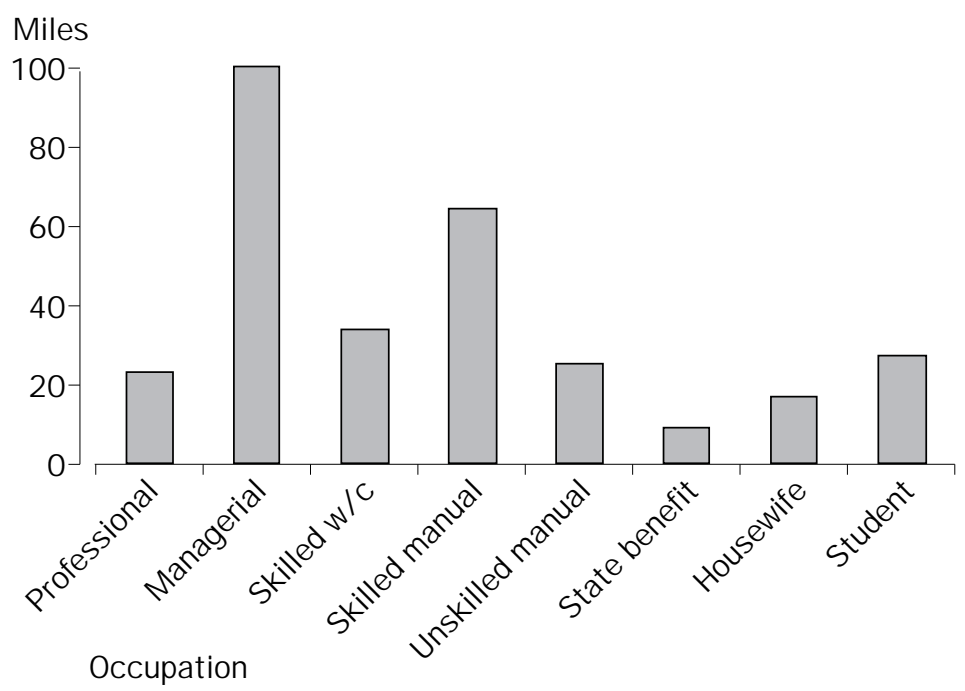

opportunities. The problems of isolation for people in rural areas can mean that deprivati on is hidden. In these instances, the discussi on is usually focused on those who have slipped from genteel affluence to impoverishment that often the poor themselves find difficult to admit to. A nother for $m$ of deprivati on is reflected in Spike's comment: it is the boredom and frustration of travel poverty.

Young women in the sample were much more likely to be escorted by parents and/ or boyfriends than theyoung men. Their choices about travel were frequently curtailed by fears about their safety, and sometimes by the cost of travelling. The availability of finance for cars was also affected by gender.

In this study, none of the women but 17 per cent of male respondents had their cars paid for by sources such as "company", "someone else" or cars were jointly purchased by parents and children.

Travel poverty does not have any objectively measurable effects, unlike, say fuel poverty. In this study, we concentrated on the 
Amanda Root and

William J. Fielding

Placebo or panacea?

Rural transport corridors:

some social and

environmental issues

World Transport Policy \&

Practice

2/ 4 [1996] 20-27
16-29 year-ol d age groups and found that they did experience lack of choice about travel . The public transport in the travel corridor did provide some extra choice, albeit only to the extent of buses and trains being used for 6 per cent and 5 per cent of all journeys respectively. The quali tative data suggests that, for this age group, mobility might be most effectively enhanced by reductions in fares and alter native transport schemes such as lift-sharing, shared taxis, or pay-asyou-ride type of car-sharing which could allow autonomy and some (perceived) degree of personal safety, especially at night.

\section{Travel corridors and the} environment

Energy use is directly linked to carbon di oxide emissions, which contribute to climate change. The impact of the journeys on energy use have been estimated in Table V. These figures include journey length with mode and passengers as the main variables. Estimations based on figures by Banister (1992). Car occupancy is assumed to be 1 for car drivers, but 2 for car passengers. Buses and trains are assumed to be 33 per cent full electric trains. Both diesel suburban and Intercity trai ns use more energy. Similar figures, but with a lower MJ figure for cars, are given in Hughes (1993).

The environmental gain made $(2,300 \mathrm{M})$ per day, 16,000 MJ per week, 839,500 MJ per year) amongst those sampled in Cholsey is probably as a result of the existence of rail use. The energy use in Chalgrove is 0.0191

$\overline{\text { Table V }}$

Estimated energy use and mode of transport

\begin{tabular}{lcrr}
\hline Mode & $\begin{array}{c}\text { Estimated energy use } \\
\text { MJ/ passenger mile }\end{array}$ & $\begin{array}{r}\text { Chalgrove } \\
\text { (MJ/ day) }\end{array}$ & $\begin{array}{r}\text { Cholsey } \\
\text { (M)/ day) }\end{array}$ \\
\hline Bus & 0.83 & 164 & 318 \\
Car & 3.21 & 10,245 & 8,349 \\
Company car & 3.21 & 1,944 & 1,435 \\
Cycle & 0.10 & 8 & 15 \\
Friend's car & 1.60 & 564 & 15 \\
Hitchhike & 1.60 & 78 & $\mathrm{~N} / \mathrm{A}$ \\
Minibus & 1.15 & 141 & 15 \\
Motorcycle & 3.13 & 141 & $\mathrm{~N} / \mathrm{A}$ \\
School bus & 0.83 & 7 & $\mathrm{~N} / \mathrm{A}$ \\
Taxi & 1.15 & 9 & 8 \\
Train & 0.89 & $\mathrm{~N} / \mathrm{A}$ & 595 \\
Underground & 1.08 & $\mathrm{~N} / \mathrm{A}$ & 11 \\
Walk & 0.25 & 43 & 45 \\
Total: MJ per day & & 13,345 & 11,006 \\
Average miles per person & & 33 & 34 \\
Number of people in sample & & 145 & 134 \\
\hline
\end{tabular}

MJ / mile/ person/day and 0.0179

MJ / mile/ person/ day in Chol sey. If the 679 miles travelled on trains had been undertaken by car, then the energy use for Cholsey would rise to $0.0204 \mathrm{MJ} / \mathrm{mile} /$ person/ day.

Cholsey uses approximately one-fifth less energy than Chalgrove. The difference in energy use may partly be attributable to a convergence of more journeys in a "transport corridor" and better public transport in Cholsey compared to Chalgrove. More than double the miles were travelled by environmentally friendlier modes of transport, such as public transport or cycle, in Chol sey than in Chal grove (Table V).

The proportion of "green" miles is strongly affected by the rail service from Cholsey. Rail ways miles account for $\mathbf{4 8}$ per cent of all distance by environmentally friendly travel modes. This points to the particular environmental usefulness of rail corridors. In Figure 5 all the groups except the unskilled manual workers, those on state benefit and the housewives used the train. This strongly suggests a cor relation with aver age or above average income and rail use, a correlation which is broken, perhaps, by the students because they are allowed discounted rail fares.

\section{A challenge for planners}

The problems of rural transport nearly always involve the need to develop popular community services without high infrastructural costs. Many innovative rural transport solutions such as post buses, liftsharing or shared taxis are successful but have two main problems:

1 they are relatively unattractive to those who might otherwise travel by car; and 2 they often require subsi dies - ei ther financial or the unpaid work or goodwill of volunteers - to ensure they can run.

From the evi dence above, it appears that public transport corridors might be a way of encouraging use of public transport in rural areas - al lowing housing devel opment in greater concentrations could enable the commercial viability of transport corridors.

Public transport corridors can offer a lowpublic-cost alternative that will allow greater personal travel, if demand continues to grow. The changes to land-use planning which would allow the fur ther devel opment of public transport corridors, through encouraging certain types of development at "nodes" along these corridors is within the powers of County Councils, the UK 
Amanda Root and

William J. Fielding

Placebo or panacea?

Rural transport corridors:

some social and

environmental issues

World Transport Policy \&

Practice

2/ 4 [1996] 20-27 equivalent of regional planning authorities. Taking this opportunity would be in accord with current planning guidance, which encourages the adoption of measures desi gned to reduce the need for car travel, e.g. Department of the Environment and Department of Transport (undated).

There is consi derable pressure for councils to devel op road corridors, as some influential groups believe these encourage economic development. However, this has been shown not to be the case. Whitel egg (1994) writes

50 years of economic geography on both si des of the Atlantic have clarified exactly which factors encourage new firm creation, job creation, inward investment and the locational decisions of entrepreneurs. Transport costs are not a significant variable and rarely account for more than 2 per cent of value of sales.

Whitelegg's article shows that roads do not contribute significantly to economic prosperity.

“...E vidence presented heresuggests rail ways have theability to competewith car travel. Many of the privatecar trips wereshown to beal ong 'corridor' routes, demonstrating, prima facie, opportunities for switching to publictransport...."

There are difficulties with the development of public transport corridors:

1 It would appear, from the resul ts described here, that rail corridors are not, under current circumstances, likely to al leviate travel poverty to any significant extent. The costs of travelling by rail are, on the whole, prohibitive to people on lowincomes or the unemployed.

2 There is also a problem that not all villages will belikely to be on, or amenable to the creati on of, a publi c transport corridors. What happens to those that are not on one? The number of railways is limited and the creation of new railways is rare. The likelihood is that the current privatization of the UK railway is unlikely to change this situation. However, there are also possibilities for developing better walking and cycling facilities, which might be more appropriate than public transport in some areas. Sustrans, a charity, has developed a national network of cycle tracks, often on disused railway lines, and has demonstrated the attractiveness of nonmotorized rural and urban "corridors", for example.

3 If councils were to subsi dize services on public transport corridors in order to support the development of a "virtuous spiral" of growing services and increased usage, then this might mean, in current financial circumstances, cutting services from elsewhere. Is it justifiable to devel op a high quality public transport service in one area if this means depriving some people of an infrequent bus service?

The proportion of journeys which have a destination accessi ble by public transport is higher from Cholsey than Chal grove, suggesting that the public is using centres that are served by public transport and might be willing to use more public transport with an acceptablelevel of service.

One oppor tuni ty exists for extending the range of accessibility of rail services via connecting bus services, which is that the changing legislative structure will allow more combined bus service and rail service ownership in the same geographical area, something which was not allowed under previous regulations. This expansion of ownership might be used to ensure better intermodality and complementary of bus and train services. Stagecoach, a large service provider, has al ready opened an innovative bus service that joins a train service in Hampshire, southern England.

\section{Conclusions}

This article supports the idea that public transport cor ridors could provide environmentally friendlier for ms of travel in some rural areas. Rail transport corridors were shown to increase modal choice but they were not found to be affordable by some groups such as the those dependant on state benefits - whose travel poverty is directly linked to low-income.

Evidence presented here suggests rai Iways have the ability to compete with car travel. Many of the private car trips were shown to be along "corridor" routes, demonstrating, prima facie, opportunities for switching to public transport.

The main environmental advantages of rural public transport corridors appear to be that they reduce energy use from transport, and potentially, allow for an increase in personal mobility while keeping emissions at current, or similar levels. This aspect could contri bute to the meeting of the inter nationally-agreed "greenhouse gas" reductions. Without a change in fiscal measures, rural travel corridors do not hel $p$ the travel poor much. They are not a panacea, or a placebo, but one small move in the direction of sustainability. 
Amanda Root and

William J. Fielding

Placebo or panacea?

Rural transport corridors:

some social and

environmental issues

World Transport Policy \&

Practice

2/ 4 [1996] 20-27

\section{References and further reading}

ACRE (Action with Communities in Rural England) (1994), Rural Life: Facts and Figures, ACRE, Cirencester.

Banister, D. (1992), “Energy use, transport and settlement patterns", in Breheny, M.J. ( Ed.), SustainableDevel opment and Urban Form, Pion, London.

Department of the Environment and Department of Transport (undated), Planning Policy Guidance 13: Transport, HMSO, London.

Greene, D. and Santini, D. (Eds) (1993), Transportation and Global ClimateChange, American Council for an Energy-Efficient Economy, Washington, DC.

Henshaw, D. (1994), TheGreat Rail way Conspiracy, Leading Edge Press and Publishing, Hawes, North Yorkshire.
Hughes, P. (1993), Personal Transport and theGreenhouse Effect, Earthscan, London.

Oxfordshire County Council (1994), Oxfordshire Devel opment Trends, Oxfordshire County Council, Oxford.

Root, A., Boardman, B. and Fielding, W. (1996), Rural Travel and Transport Corridors, Environmental Change Unit, University of Oxford, Oxford.

Stanner, D. and Bourdeau, P. (Eds) (1995), Europe's Environmental Assessment, European Environmental A gency, Copenhagen.

Stokes, G. (1995), Rural Transport Policy in the 1990s, Institution of Civil Engineers, Transport J ournal, London.

Whitelegg, J . (1994), Roads, J obs and the Economy, Green peace, London. 


\title{
Freight transport, food production and consumption in the USA and Europe (or, how far can you ship a bunch of onions in the USA?)
}

\author{
Stefanie Böge \\ Wuppertal Institute for Climate, Environment, Energy, Wuppertal, Germany
}

Focuses on freight transportation, food supply and consumer behaviour in the USA and Europe, especially Germany. Finds that on both sides of the Atlantic, in freight transportation and food supply there are many differences as well as similarities. The main differences are that the USA has a bigger land area and larger, more concentrated economic units. Naturally, therefore, one finds a higher volume of long distance freight transport than in Europe. Similarities can be observed such as the trend towards privatization and liberalization, to more extended suburbanization or to an unreflected way of consumer behaviour. In addition raises some new questions: is the "technological solution" of environmental problems the only way? What can be done to include lifestyles and consumer behaviour into a new strategy?

\section{Introduction}

This is a condensed version of a report undertaken for an Environmental Fellowship from the German Marshall Fund (GMF) of the USA for which the author was selected in 1995. The GMF's environmental programme is referred to as "Building US - European Environmental Partnershi ps". It focuses on local, regional and national responses to the threat of global warming. The main focus of the fellowship report was on freight transport, food supply and consumption patterns.

In general the answers to the environmentally problematical development in freight transport are technical ones namely that: administrators and scientists should try to improve engi nes, transpor tation modes and logistic strategies. Freight transport is influenced by production, consumption, land-use patter ns and lifestyles, but these fundamental deter minants of increasing traffic are rarely given the same priority as the technical solutions.

Freight transport is heavily influenced by the nature of countries' economies (i.e. what and how they produce, and where they produce and consume it), as well as their size and physical geography. Because the USA and Western Europe are quite dissimilar in size, geography, production and consumption characteristics, their freight systems have many differences.

However, on both sides of the A tlantic there has been an increase in the travelling distances made by freight transpor tati on, and with that an increase of environmental problems from freight. Reasons for the distanceintensive development in production and consumption can befound in transport policies, the locations and production patter ns of the (food) industry, the policy and location of retailers, the principles behind agriculture, the shopping behaviour of consumers and land-use patter ns. To reduce the environmental impacts of freight transportation, it is necessary to consi der the nature of food supply as a whole (as well as automobile usage for shopping); freight transport is a result of policies and distance-intensive lifestyles.
Transport policies in the USA

The USA has more than five times the land area of former West Germany; UK; France; Italy; Sweden and Norway (US Congress, Office of Technology A ssessment, 1994) and therefore more long distance freight transport. In general, this long di stance travel is not seen as a problem in the USA. It is common that food is produced on the west coast and sold on the east coast and ther efore shipped over thousands of miles.

Transport policy in the USA concentrates on efficiency standards, but in spite of the better fuel efficiency in the vehicle fleet, the energy consumption and emissions are growing, especially in freight transportation (Schipper and Scholl, 1995). New regulations (i.e. a $\mathrm{CO}_{2}$-tax), so many decision makers say, are opposed to the free enter prise market economy. Because of the extreme recession in the economy in the last five years, politi cians are very careful with any regulations. As in Europe freight issues are not very important in planning (on the official side planning is seen as communism or socialism), even though consciousness of the problem is growing.

Although thereare no formal freight transport policies showing how this sector should be handled in a more environmentally sound way (neither in the Clean Air Act nor in the Climate A ction Plan), there are some initiatives at regional level to improve the current freight system. The basis for that is the Federal Inter modal Surface Transportation Efficiency Act (ISTEA), which expanded the role played by metropolitan planning organizations in regional transportation decisions affecting freight (J ones, 1995). In addition some regions devel op Air Quality Management Plans which include mobile emission sources such as trucks and trains[1] and there are efforts to find out how much material is transported within a region and to resolve the lack of knowledge about freight data[2].

In general, as in Western Europe, there is an assumption that the costs and prices of freight transport are too low. However in the USA this is a more theoretical debate than in Europe because there is no seri ous sign 
Stefanie Böge

Freight transport, food

production and consumption

in the USA and Europe (or,

how far can you ship a bunch

of onions in the USA?)

World Transport Policy \&

Practice

2/ 4 [1996] 28-3] (there is even a retreat) from politicians, and, nobody can predict what would happen if prices were increased. Would this reduce road traffic and lead to more environmentally sound transportation modes? European gasoline prices are 2.5 times higher than in the USA, but there is an increase in road freight transport here as well. Therefore, pessimi stic representatives point out, nothing will change with higher prices - especially higher gasoline prices. Everyone knows that one cannot raise prices so much that a significant change will happen. The optimi stic view is not only to raise fuel costs (only 4-5 per cent of operation of the vehicle is fuel cost) but al so change other factors which have effects on trucking (i.e. fixed costs). It is estimated that if transportation costs for road freight are doubled, there will be more rail and intermodal (especially with double stacked containers), and more regi onal self-sufficiency.

Never thel ess, the cur rent situation is different. Because of the fixed costs for running a truck, short distances are much more expensive than long distances, even empty back movements are not a seri ous cost factor. Beyond that the frei ght sector is more elastic than passenger transport, because there is the possibility to pass on the higher prices to consumers. The situation in freight has stabilized on a distorted basis and the system can continue in the same (environmentally bad) way, although there are some clever environmentalists with good ideas. To reduce long distance (road) freight transport, much more than a raise in prices will be necessary.

Food and freight transport

Compared with other sectors, transportation costs in the food sector are relatively high. The delivery distances of low value agriculture commodities such as cattle and soya beans are dependent on transportati on costs. In general, raw materials (low value products) are transported over small, and processed products over longer, di stances. Ther efore one important question in agriculture is how to minimize transportation costs.

However from the production standpoint, the main decision concer ns finding the market for the product. The east coast of the USA has very little basic food production and agricultural farming is cheaper on the west coast. As a result the largest food industry can be found in California, Oregon and Washington State. For reasons of low production costs, food comes mainly from the west coast and is sold all over the USA. Although theoretically no potatoes are shipped over thousands of miles because it would be too expensive, one can buy bunches of fresh onions from Califor nia in Washington, DC (for 90 cents).

As in Ger many, an increase in organic agricul ture can be observed. Unfor tunately, transportation issues are not taken into consideration with organic or healthy food, al though long distance transport has an impact on the quality. Farmers, manufacturers, shopkeepers and consumers pay little attention to these issues. Many A mericans suppose that products from Europe are healthier (or safer). This might be because of the defined standards and labels for organic food in Europe. Products in Europe are tested by independent associations in which consumers trust whereas in the USA there are no comparable standards or labels which are valid for the whole country. Certain states and manufacturers try to fix their own standards, but they are more or less without any control and so have gained little trust. There is no agreement on what form standards should take.

There is therefore much more confidence in European food and US health food shops contain a lot of products, such as crisp bread, cheese or juice from Switzerland or Germany. F ur ther more, as with conventional food, organic fruits and vegetables are produced mostly on the west coast, so that a lot of these products are shipped thousands of miles to the east coast. There is a similar structural situation for organic food in Germany, but on a smaller geographical scale. When organic food first became avai lable, the demand for it tended to be concentrated in South Ger many and thus organic food had to be shipped over hundreds of kilometres to organic food shops. Now, after some years of supply, one can find much more organic farming and food processing in all parts of Germany, so that the delivery distances of such products are decreasing.

With the growing demand for organic food the situation in the USA is changing in the direction of more decentralized production patterns. Especially on the east coast there is a growing interest to get more regional and local products, but thelack of organic production sites and adequate infrastructure still make it difficult to serve the market with "Iow distance organic food". Nevertheless, one can find some initiatives which are heading in this direction.

Regional and local food production in the USA is supported from diverse initiatives, especially from food co-operatives. In some States such as M innesota, these communities are very strong. They realized that transportation changed the economy towards a global mass producti on and mass market 


\section{Stefanie Böge}

Freight transport, food

production and consumption

in the USA and Europe (or,

how far can you ship a bunch

of onions in the USA?)

World Transport Policy \&

Practice

2/ 4 [1996] 28-31 with the result of loosing more and more regional economic power. Therefore a growing number of local initiatives (i.e. direct delivery initiatives) try to keep small production sites in their region, in food and other sectors. A reason for this is not least to create and preserve jobs. Cities are supporting such initiatives (i.e. community marketing or far mer markets). However, consumer behavi our today is generally in contrast with the i deas of a sustainable food system with less transportation.

\section{Consumer and travel behaviour}

Product demands and shopping patterns in Europe are becoming morelike those in the USA:

- people buy moreand more processed food (the main reason for this is given as the time-saving aspect);

- people buy many more products at one time, i.e. once a week or even once a month; and

- more and more people use their own cars to go shopping (it is estimated that 99 per cent of Americans go shopping by car).

These trends are directly related to more freight and more passenger transport and, further more, to other land-use patterns (large centralized production and large retail sales units) which affect consumer behaviour. In general, processed food is cl osely associated with more freight transport. More materials are used, for which more production steps, and with that more transhipments, are necessary. In addition, various packaging materials are needed. However, in addition to freight transport being stimulated by the current food system, by buying more products at one time, it is necessary to carry all products in a car and, because of existing land-use patter ns (bi g super markets outsi de the cities), almost everyone needs a car to go shopping. This initiates the vicious circle of land use and traffic.

Because of the increasing number of food malls outsi de cities, shops in small towns have become very specialized and grocery stores for daily needs are few in number. Supported by this consumer behaviour, there has been a change from a nation of small busi ness owners to much fewer, but larger, operations. Stores are becoming larger and ther efore need more consumers to remain profitable. On the other hand, large supermarkets can offer better prices and a "better" quality of food, and consumers see advantages in using such facilities. The result is that people have to travel longer distances to buy daily things.
An identical situation in consumer behaviour, traffic and land-use patterns can be observed between West and East Ger many, especially before but also after, the reunification - again to a lesser degree. Prior to reunificati on there was a low ownership of private cars and therefore East Germany had a much more dense and mixed land use. People went to the shops on foot and bought produce more frequently because they could not carry so much. Even today big department stores from West Ger man compani es have problems in working profitably because people do not buy enough. But with the rapidly growing ownership of private cars this phenomenon disappears.

It seems that transport and consumption behaviour is not, or almost not, changeable because it is related with other issues such as land-use patterns, prices or comfort. But some people are optimistic: if the public understands what the problem is there is a potential that they will change behaviour, as seen with the anti-smoking campaigns in the USA. People are more and more aware of what they eat and safe food has an increasing importance.

\section{Conclusions}

On both sides of the Atlantic one can find two groups of environmentalists: people who want to improve existing systems and people who want to change value systems and standards of values. Technical improvements are - compared with values or behaviour - easy to imagine and ther efore most of the environmentalists believein such solutions. The question however is whether such "solutions" can bethe only response to the threat of global war ming. $\mathrm{CO}_{2}$-emissions (especially in the transport sector) are increasing, although there were enor mous technical improvements in the past. Therefore values and behaviour should play a bigger role in the future. Not least because $\mathrm{CO}_{2}$ or other emissions are not the only problem but the decrease of our quality of life, which is related, i.e. in the USA, with the problem of unsafe food or in Europe with the problem of increasing need of space for motorized traffic. The first step for changing values is the understanding of connections, in this case between transport, quality of food and the quality of living space.

Infor mation and education are very important to change values, although it seems that people have too much information about too many (useless) issues. For example, advertising can be used for showing people how food is produced and how fresh and healthy it can 
Stefanie Böge

Freight transport, food

production and consumption

in the USA and Europe (or

how far can you ship a bunch

of onions in the USA?)

World Transport Policy \&

Practice

2/ 4 [1996] 28-31 be if it is consumed in the same region where it is produced. Shorter transport distances are connected with a better quality, a better taste and a higher vari ety of food. Such information should not be seen as additional but instead of the current information.

It is said that the USA is the country of choice and possibilities. Looking closer, this vari ety seems an illusion as the amount and the inter national choice of products has obviously increased, but the system behind food production is based on very homogeneous products (a few kinds, same si ze, same taste, same colour) which are easy to use for mass production. Moreover, the inter regional variety (different kinds, size, taste and colours of fruits, vegetables or animals) has decreased dramatically. As Simone de Beauvoir described the USA as far back as 1947:

...A nd soon one finds out, that all chocolates have under the colourful wrapping the same peanut taste and that all best-sellers tell the same story. And why sel ecting this toothpaste of all toothpaste? This useless overabundance has a taste of mysticism. There are thousands of possibilities - and it remains al ready the same. You have a thousand fold choice - and one is as much as wor th like another. The A merican citizen can use his freedom without realizing that such a life is not free (de Beauvoi r, 1988).

Today it seems that people in the USA are more aware of this than in Europe, and that Europe is believing in the myth of "useless overabundance" much more.

However compared with the USA one can find in Western Europe much more environmental consciousness and moreactivities for a sustainable way of life (especially in food production and consumption, even a little bit in automobile usage). This does not mean that the world looks better in Europe but it seems that together with the more diverse and smaller structures there are more opportunities to create a sustai nable way of li fe.

\section{Notes}

1 For example, The1994 Air Quality Management Plan of theSouth Coast Air Quality Management District and theSouthern California Association of Governments, September 1994.

2 For example, Truck Operations Survey Results, South Coast Air Quality Management District, prepared by Lockheed IMS, LA, March 1993.

\section{References}

de Beauvoir, S. (1988), Amerika Tag und Nacht. Reisetagebuch 1947, (America from Day to Day: Travel Diary 1947), Rowohlt, Hamburg, p. 25.

J ones, D.W. (1995), I nter modal Perfor manceM easures for theBay Area Transportation System, Summary report for the Metropolitan Transportation Commission, Oakland, CA, J une.

Schipper, L. and Scholl, L. (1995), “Keep on truckin': energy use and $\mathrm{CO}_{2}$ emissions for freight", I nternational Energy Studies, Draft of 27 October, Lawrence Berkeley National Laboratory, Berkeley, p. 10.

US Congress, Office of Technology Assessment (1994), Saving Energy in US T ransportation, Government Printing Office, Washington, DC, J uly, p. 87. 


\title{
Car-free households: who lives without an automobile today?
}

\author{
Ulrike Reutter \\ Research Institute for Regional and Urban Development of the Federal State of \\ North Rhine-Westphalia, Dortmund, Germany \\ Oscar Reutter \\ Wuppertal Institute for Climate, Environment and Energy, Wuppertal, Germany
}

Considers methods to reduce private car ownership. Argues that conventional strategies are approaching the limits of their efficacy. Concludes that the solution lies in implementing car-free zones.
World Transport Policy \&

Practice

2/ 4 [1996] 32-37

(c) MCB University Press

[ISSN 1352-7614]

\section{Introduction}

Many people have come to recognize private motor vehicle traffic as being one of the major driving forces behind declining environmental and residential qualities in the cities. Rising numbers of motor vehicles and increases in the mileage covered by privately owned vehicles bring with them growing accident risk, Iand consumption, soil contami nation, overall resource depletion and energy use with the concomi tant $\mathrm{CO}_{2}$ problems, wastes in the manufacture and disposal of automobiles, and noise and air pollution. The countenance of the city and the quality of life in cities both suffer.

Conventional strategies for solving such problems, including widespread traffic calming or optimizing motor vehi cle technol ogy, are approaching the limits of their efficacy. They do indeed reduce the stress on the environment but the gains are more than offset by increasing loads emanating from an unbroken rise in the numbers of vehicles and volume of travel. This makes it necessary to abandon a taboo in our thinking and instead develop planning concepts ai med at reducing the number of automobiles. In this effort regi onal, urban and traffic planning should provide incentives to those househol ds which even today do without an automobile and encourage those who are consi dering el iminating a car now on hand in the household so that they will actually relinquish that vehicle. Car-free neighbourhoods within towns would make it possible for people who do not own a vehicle at present and all those who would like to do without a car in the future to experience, both individually and collectively, the benefits which liberation from the private car offers. All the resi dents, children as well as adults, could then move freely within the entire public roadway area, not endangered by vehicle traffic, and beable to cycle, play or simply sit and relax in this newly reclaimed space - without automobile exhausts and noise.

The data reproduced below stem from broad-based Ger man statistics and above all from a telephone survey embracing 146 car- free households selected at random in Dortmund; we conducted this survey in November of 1992 in conjunction with writing our dissertation (Reutter and Reutter, 1995). Herea "car-free" household is defined as one which has not owned a vehicle for at least a half year and does not have access to ei ther a company car or a motorcycle. Our empirical results are representative for the car-free households in Dortmund.

How many car-free households are there?

In 1993 Germany was home to a total of 81.3 million people; at the same time 38.9 million passenger cars were registered (cited in German Economic Research Institute, 1994, p. 7). In the period since the first Income and Consumption Sampling (ICS) which was conducted in 1962, the number of non-motorized households has fallen continuously as a result of ongoing mass motorization, down from the original 73 per cent of all households (Figure 1). The ICS conducted in J anuary of 1993 revealed that of the 35 million households in Germany, about 10 milli on (28 per cent) do not have a car, while 25 million households ( 72 per cent) own at least one vehi cle. A bout 18 per cent of the total German population lives in car-free households; expressed in figures, that comes to 14 million of the some 80 million people in Germany (Ger man Federal Statistics Office, 1994, see Reutter and Reutter, 1994, pp. 112-18, for detailed infor mation on the sociodemographic structure of car-free households.) On the national average, at least one household in four does not own a vehicle. It is thus not possible to speak of "full motorization" in Germany. In Dortmund about 81,000 (32 per cent) of the total of 255,000 households do not own a vehicle (Figure 2).

These figures clearly indicate that, when planning and setting up car-free zones, the people who today al ready do without a car represent consi derable demand or market potential. 
Ulrike Reutter and Oscar

Reutter

Car-free households: who lives without an automobile today?

World Transport Policy \&

Practice

2/ 4 [1996] 32-37 $\overline{\text { Figure } 1}$

Car-free households in western Germany through time

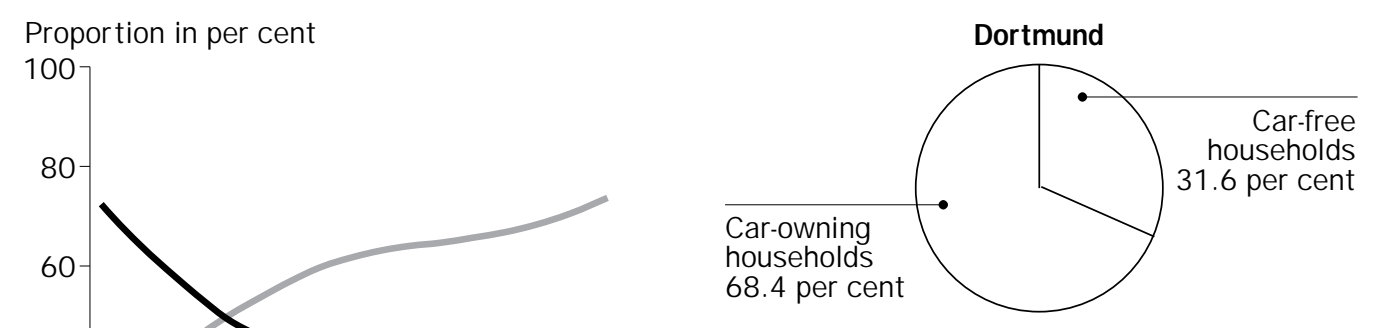

Sources:

Pöschl S. 925 (1993):

Euler (1989, 5.314), S. 314;

Reutter and Reutter (1995)

Where are the car-free households located?

The more "urban" the surroundings, the greater the number of car-free households. The proportion of non-motorized households rises with the size of the town or city. Taking the average of all cities and communities in Germany, the share of car-free households lies at 28 per cent; in the larger towns with 100,000 residents or more, this proportion is consi derably higher. In fact, in the major cities with populations exceeding 500,000, carfree households now account for more than 40 per cent of the total.

Within these large cities, the percentage of car-free households in inner-city and mixeduse areas is especially high. In areas of this type within the city of Dortmund, almost half of all the households are without a car (46.4 per cent); only slightly more than half of all households there have one or more vehicles at their disposal (53.6 per cent) (see Figure 3).

These findings clearly indicate that the large cities particularly lend themsel ves to the planning of car-free zones, and within a city the inner-city resi dential and mixed-use areas are especially suitable for car-free zoning. Let us summarize the factors here:

- almost half of the households in the innercity residential areas in the large cities in western Germany al ready live wi thout a car;
Cities with 100,000-500,000 residents

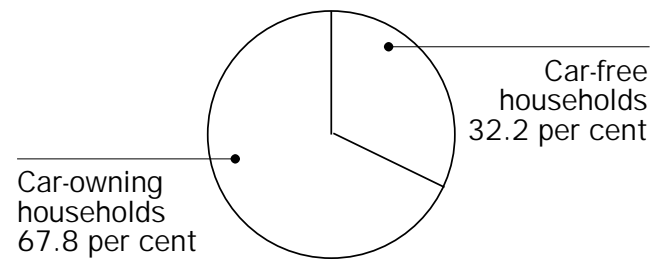

$\overline{\text { Figure } 2}$

Share of car-free households in Dortmund and in large western German cities

Cities with more than 500,000 residents

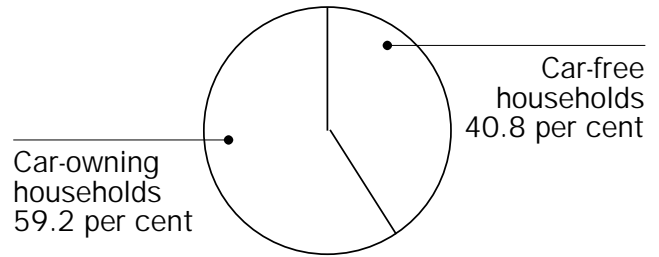

Sources: Authors' own results from a telephone survey of selected, representative households in Dortmund in November 1992, $N=640$ households, German Federal Statistics Office 1994a; unnumbered; income and consumption sampling in J anuary 1993 (Reutter and Reutter, 1995)

- these ar eas are char acterized by a comparatively great number, vari ety and densi ty of activities which represent destinations for individual jour neys, including residential areas, workplaces, shopping facilities and cultural and recreational facilities;

- these destinations can easily be reached using the so-called "green modes" namely on foot, by bicycleand with public transport.

The logical conclusion is that future focus should be on identifying such quarters, capitalizing on the favourable existing situation there, in addition to pursuing citywide planning projects to promote car-free living.

Car-free city zones in inner-city residential and mixed-use areas should be set up both within existing urban structures and in newly redevel oped areas - including those built on rehabilitated inner-city land such as barracks and other military facilities or abandoned commercial properties, evacuated 
Ulrike Reutter and

Oscar Reutter

Car-free households:

who lives without an

automobile today?

World Transport Policy \&

Practice

2/ 4 [1996] 32-37

Figure 3.

Car-free households according to the structure of the respective residential area in Dortmund, in November 1992

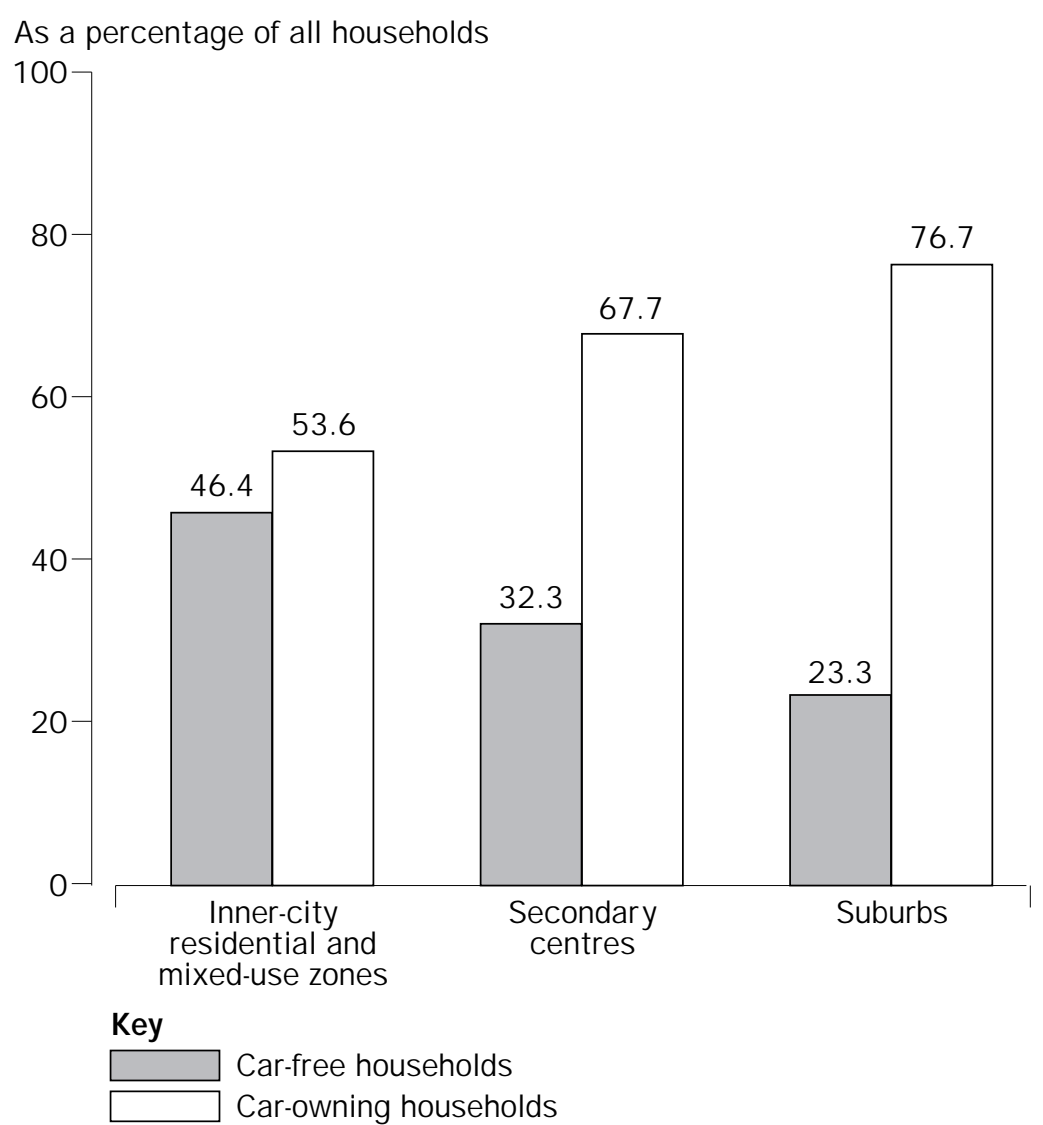

Source: Author's own results from a telephone survey of selected, representative housholds in Dortmund in November 1992, N=146 households + 146 car-free households (see Reutter and Reutter, 1995)

former railway freight yards. Conversion and re-development projects in existing residential areas over longer periods of time areso decisive because, in comparison to the volume of new construction, the bulk of available housing is to be found there. In addition, quite a large number of non-motorized households are located in such areas today; if they wanted to enjoy the collective advantages of car-freeliving they would otherwise first have to rel ocate. Older citizens in particular, no longer wanting or able to move house, would have hardly any prospects for enjoying the benefits of a car-free neighbourhood unless projects were to be carried out in existing residential areas.

Who currently lives without a car?

In addition to the role played by the character of the neighbourhood itself, the sociodemographic household type to which a given unit belongs correlates to a large degree with its daily internal organization in regard to time and distances. If, for example, many people live in a single dwelling, their activiti es have to be jointly arranged. If there are children in the home, their activities have to be co-ordinated with those of the parents and more often than not, of the mother alone. The daily rhythms of older people are quite different from those of young people; if members of the household are gainfully employed, then they face very specific constraints in ter ms of time and space.

Mobility research efforts and particularly action radius studies (time and space) show that three socio-demographic characteristics:

- the ages of the adult members of the household;

- their participation in the working world; and

- the presence of children in the household; can be used to describe quite accurately the si tuation within which a household operates, i.e. the family's rhythms for $m$ the basis for 
Ulrike Reutter and Oscar

Reutter

Car-free households: who lives without an automobile today?

World Transport Policy \&

Practice

2/ 4 [1996] 32-37 specific time-and-space constraints (see Holzapfel, 1980; Holz-Rau, 1990; Kreibich et al., 1989; Mentz, 1984; Neuwerth, 1987; Reutter et al., 1991).

A pplied to the non-motorized households in Dortmund, three situationally homogenous types of car-free households emerge:

1 retired households - aligning with the trend;

2 working households without children countering the trend;

3 working households with children - also counter to the trend.

Taken together, these threetypes describe 93 per cent of all car-free households in Dortmund (Figure 4).

The retired households in line wi th the trend include:

- those made up of older and elderly persons, where the individual responding to the survey was 55 years of age or older;

- in which there are no working adults;

- in which there live no children under 18; and

- in which the adults are reti red or have taken early retirement or are housewives.

The members of these households have to consider only relatively minor outsideconstraints in ter ms of space and ti me since none of them is involved in gainful employment. They must cover the distances and routes required for personal business (shopping, errands, banking, medical appointments, etc.) and for lei sure-time activities. A mong those older households in Dortmund where the person responding to the survey was 65 years of age or older, about three-quarters were single-person households, comprising almost exclusively women living al one; about one-quarter were two-person households where the only constraints arise from the need for co-ordination between the two

\section{$\overline{\text { Figure } 4 .}$}

Situation-homogeneous types of car-free households in Dortmund, in November 1992

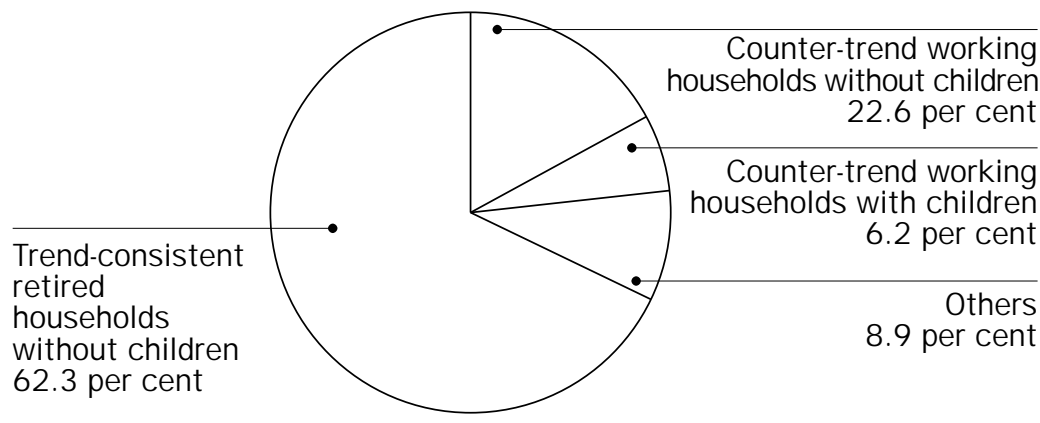

Source: Authors' own results from a telephone survey of selected, representative households in Dortmund in November 1992, N = 146 households (see Reutter and Reutter, 1995)

adults. Four out of ten retired households in line with the trend could, in their own estimation, afford a car. In Dor tmund retired households account for almost two-thirds of the non-motorized househol ds; they are estimated to number about 54,500.

The structure of the retired households cor responds precisely to the trend which can be read from the data for western Ger many (Reutter and Reutter, 1994), the proportion of car-free households being relatively high in the groups of households

- made up of older or el derly respondents;

- where the respondents are not empl oyed;

- without children; and

- in the smaller households, particularly among the one-person units.

Included in those "working households without children" which run counter to the trend are the:

- young and middle-aged households where the person responding was in the employable age bracket, from 18 to a maximum of 55 years;

- households in which at least one adult is gai nfully employed; and

- households in which therelive no children less than 18 years of age.

The working members of the household must deal with major limitations in ter ms of time and distance, since they must pursue the "mandatory activity of working" at fixed workplaces and during fixed working hours. A Iso affected by these constraints are the other activities of these particular household members such as taking care of personal business and pursuing lei sure-time activities; the other adult members of the household are al so affected even if they are not working. When the members of the household want to spend free time together, for instance, they are restricted to the early mornings, late after noons and evenings, and weekends, all times at which public transit services are considerably sparser than during nor mal working hours.

In Dortmund at least half of these households are single-person households. A bout four out of ten households are two-person households and only about 5 per cent include three or more persons in which the need to orchestrate activiti es among the adult members of the household is particularly evident. Two-thirds of the counter-trend working households without children could, in their own opinion, afford to keep a vehicle. In Dortmund this type of household structure, esti mated to number 19,700 , accounts for al most a quarter of the car-free households.

When it manages without a vehicle, the "working household without children" 
Ulrike Reutter and

Oscar Reutter

Car-free households:

who lives without an

automobile today?

World Transport Policy \&

Practice

2/ 4 [1996] 32-37 behaves exactly contrary to the trend which can be gleaned from the data for wester $n$ Ger many (Reutter and Reutter, 1994), the proportion of car-free households being relatively low among those households with:

- younger or middle-aged respondents;

- gainfully employed respondents; and

- higher net household incomes.

To be counted among the "working households with children" which operate contrary to the trend are households with:

- young and middle-aged where the person replying was of employment age, from 18 to 55 years;

- at least one adult gai nfully employed; and

- at l east one child less than 18 years of age.

In these households - almost 90 per cent of which include three or more persons in Dortmund - the activities and associated jour neys taken by the adults and the children must be particularly carefully co-ordinated and - especially where smaller children are present - closely synchronized. The organizational effort in this type of household is enormous. Family members have hi gh mobility requirements to cope with the need to coordinate time and the journeys resulting from the variety of activities to be carried out: travel to and from work at regular times and fixed locations, tending to personal business, lei sure-time jour neys and the various trips occasioned by the children all have to be har monized. This is aggravated by the increased amount of transpor tation capacity required not only for the foods and beverages needed daily but also for the equi pment used on family excursions and holidays. In their own estimation, two-thirds of these households could, without qualification, afford a vehicle. In Dortmund this group accounts for 6 per cent or about 5,500 of the car-free households.

Where the "working household without children" does not own a car, it also contradicts the trend seen in the data for western Ger many (Reutter and Reutter, 1994), the proportion of car-free households being relatively low among those household groups:

- with younger or middle-aged respondents;

- with gainfully employed respondents;

- with at least one child;

- made up of three or more persons; and

- with higher net combined income.

On the basis of the typology eluci dated here, urban planning and traffic planning should, in our opinion, support the everyday organizati on of time-and-space requi rements specific to those people now living in car-free households so that individuals who today do without a motor car will not need to purchase one in the future to cope with living in cities.

People who live without a car in the "trendconsistent retired households" are quite particularly dependent on an intact infrastructure close to thei $r$ homes to take care of personal business and to pursue leisure-time activities - particularly daily walks in the near by nei ghbourhood. This is because older people often suffer from motor and sensory limitations relevant to negotiating in traffic, complicated by physical frailty; as a consequence they are parti cularly sensitive to distances and are at high acci dent risk. Older and el derly people who organize their day-today living without a car require services which are easily reached and universally accessible (including safe walking and cycling paths) in the transportation options offered by the "green modes" so that they are not limited in their mobility.

For people wholive without a vehiclein the "counter-trend working household without children", efforts desi gned specifically to promote this target group would concentrate particularly on the evenings and weekends, namely when they are pursuing activities which are not work-related - such as shopping, running er rands and enjoying leisure activities - making the organization of daily living both simple and efficient. This is particularly important for people in car-free households with several employed individuals who can spend only a relatively small share of their time together in leisure activities. Simpleand efficient day-to-day organization for people in car-free households means in particular an arrangement of "activity destinations", such as workplaces, shopping facilities, lei sure and recreational facilities, which adheres to the principle of keeping distances short. Also essential are adequate transit services within the "green modes", particularly in the evening and at the weekend.

For those living in "counter-trend working households with children", support efforts targeted specifically at this group would also mean - over and above the measures ini tiated for the "counter-trend working households without children" - that in particular the children's infrastructure facilities such as kindergartens and day-care centres, school or recreational facilities be located near the home, where they may be easily and safely reached with the "green modes". It should be possible for children to play in the immediate vicinity of their homes safely and without hazard, these being the most accessible play areas for children and young people. In addition, improved delivery services could ease the increased transpor tati on requirements for the groceries required daily. The greater 
Ulrike Reutter and Oscar Reutter

Car-free households: who lives without an automobile today?

World Transport Policy \& Practice

2/ 4 [1996] 32-37 amount of transportation capacity needed to carry luggage and equi pment when travelling with children should be met with carefully consi dered improvements in public transport services, particularly on weekends.

\section{In closing}

The demand for car-free city nei ghbourhoods is evident. "All that needs to be done" is to implement car-free zones in the cities - when planning new areas and wi thin existing residential structures.

\section{References}

(The following publications are available in German only)

Euler, M. (1989), “Austattung privater Haushalte mit al lgewählen langlebigen Gebrauchsgütern im J anuar 1989", in Wirtschaft und Statistik, No. 5, Stuttgart, s. 307-15.

German Economic Institute (DIW) (Eds) (1994), Verkehr in Zahlen 1994, (Traffic in figures 1994), The Federal Minister of Traffic and Transportation, Bonn, Berlin.

Holz-Rau, H.-C. (1990), “Bestimmungsgrössen des verkehrsverhaltens - analyse bundesweiter haushal tsbefragungen und modellierende Hochrechnung" ("Deter mining factors in traffic behaviour - analysis of national surveys of households and model extrapolation"), Dissertation Technische Universität, Berlin.

Holzapfel, H. (1980), “Verkehrsbezi ehungen in Städten" ("Traffic inter relationships in cities"), Dissertation Technische Universität, Berlin.

Kreibich, B., Kreibich, V. and Ruhl, G. (1989), “Vom funktionsraum zum aktionsraum: wissenschaftliche grundlagen für eine modernisierung der infrastruktur- und regionalplanung", ("Scientific principles for modernization of infrastructure and regional planning"), Informationen zur Raumentwicklung, Vol. 1, pp. 51-71.

Mentz, H.J . (1984), “A nalyse von Verkehrsverhalten im Haushaltskontext" ("A nalyses of traffic behaviour in the context of the private household"), Dissertation Technische Universität, Berlin.

Neuwerth, K.-W. (1987), A bhangigkeit des Verkehrsver hal tens vom raumstrukturel len Angebot (Dependency of Traffic Behaviour on Spatial Structure), Braunschweig.

Poschl, H. (1993), “Ausstatting privater Hauschalte mit Ianlebigen, Gebrauchsgüter $n$ im J anuar 1993 ", in Wirtschaft und Statistik, No. 12, s. $924-8$.

Reutter, O. and Reutter, U. (1994), “Autofreie Haushalte, Daten zur Sozialstruktur einer unterschätzten Bevölkerungsgruppe” (“Carfree households: data on the social structure of an underestimated population group"), RaumPlanung 65, pp. 112-18.

Reutter, O. and Reutter, U. (1995), “Autofrei es leben in der stadt: ei ne beschreibung des autofreien lebens in westdeutschen Grossstädten am ende des 20. J ahrhunderts und vorschläge die stadt- und verkehrsplanung zur förderung des autofrei en lebens in der stadt, insbesondere durch die einrichtung autofreier stadtquartiere in bestehenden innerstädtischen wohngebieten" ("Car-freeliving in the city: a description of car-free living in wester $n$ Ger man cities at the close of the 20th century and suggestions for urban and traffic planning to promote car-freeliving in the city, in particular through the establishment of carfree zones within existing inner-city neighbourhoods"), Dissertation for the Urban and Regional Planning Department at the University of Dortmund, Dortmund (publication in preparation).

Reutter, O., Schütte, F.-P. and Kreibich, V. (1991), "Rei sezeitverkürzung im ÖPNV" ("Reducing travel times in local public transit"), ILSSchriften 55, Dortmund.

Statistisches Bundesamt (1994), Fachserie 15 “Wirtschaftsrechnung Einkommens- und Verbrauchsstichprobe 1993, Heft 1, Langl ebige Gebrauchsgüter" Vorabdruck noch ohne Seitenangaben (Ger man Federal Statistics Office. Professional series 15, Business calculations for income and consumption samplings, 1993, Volume 1, Consumer durables). Wiesbaden (draft publication, not pagi nated). 


\title{
Road construction and economic growth from a southern European perspective
}

\author{
Gianni Silvestrini \\ Research Unit: Energy and Environmental Policy, Cnr Ieren, Palermo, Italy
}

Claims that economic development should be decoupled from transport growth, as conventional economic growth stimulates demand for transportation infrastructure, particularly roads, with consequent environmental repercussions. Feels that potential impact on the environment should be assessed, particularly in relation to global warming. Explores alternative solutions to building new roads and gives examples from Spain, Italy, Austria and Switzerland
This article was an invited paper at the Work shop Roads and Economy organized by the European Federation for Transport and Environment, Brussels, 8 December 1995
World Transport Policy \&

Practice

2/ 4 [1996] 38-46

(c) MCB University Press

[ISSN 1352-7614]

\section{Introduction}

Transportation represents the sector of human activities that seems more difficult to adapt in a context of sustainable devel opment. Besides the well-known local environmental impacts, the increasing contribution to emissions of greenhouse gases will represent an alarming deficit in the following decades. The decision taken in A pril 1995 by the Conference of the Parties in Berlin to define by 1997 limitation and reduction objectives on greenhouse gases emissions for industrialized countries by 2005, 2010 and 2020 , could make a radical redirection of the transportati on policies obligatory.

The carbon dioxide contribution of mobility is in fact growing faster than in all other sectors and the conventi onal scenarios prepared by different governments consider a continuous increase of the emissions in the next 10-20years.

Since road transport is mainly responsible for this situation, particular attention should be devoted to the policies able to reduce the contribution of this sector, controlling the mobility demand, improving the vehicles technologies and rethinking the investments in infrastructures.

Is it possible to decouple transport from economic growth?

While during the 1970s and the 1980s it was possible to decouple energy consumption and economic activity in the industrialized countries, there are very few signs that a similar "revolution" is al so beginning for the transportati on sector. On the contrary there are strong forces, like the li beralizati on of the markets, that move in the opposite direction.

However, if carbon reduction targets are to be achieved in the following decades, it is quite obvi ous that a decoupling si milar to that achieved in the energy sector should begin, breaking the link between mobility and economic growth and reducing, at least, the transport growth rate.

The situation is well known. In Europe, freight transport has grown by about 60 per cent since 1970 and accor ding to official forecasts the trend will continue for the next 15-20 years, with rates up to 4 per cent per year. There has been a strong correlation between the economic growth and the goods tr affic growth. The elasti city index has been of 0.9 for total freight transport and 1.7 for road freight transport.

Similar data describe the passenger mobility situation. Each 1 per cent of GDP increase has seen in OECD Europe a 1.4 per cent increase in private car traffic.

Added traffic induced by new

infrastructures

The construction of a new infrastructure will inevitably create more mobility.

Considering that, according to empirical investigations over different countries and different time periods, the "Travel Time Budget" (the mean time travelled per day by an active adult) has remained stable over ti me, aver aging about one hour, and that the "Travel Money Budget" (the amount of money for per sonal mobility) is also considered constant at approxi mately 13 per cent of the di sposable income (M archetti, 1988), the ti me "saved" by an improvement of a road will be spent in addi ti onal mobility increasing the spatial access (as the diffuse urbanization of US towns demonstrates).

This tendency is, however, never considered in cost-benefit analyses. These usually assume that improved roads, or new roads, will not generate additional traffic. This fact is quite misleading in si tuations where networks oper ate cl ose to capacity, because the induced traffic affects the level of congestion of the whole network. Not considering this side effect will lead to an overesti mate of the benefits from the new proposal.

A very precise critic of the conventional planning approach has been elaborated by a special committee on behalf of the UK government, using for this analysis also the 
Gianni Silvestrini

Road construction and

economic growth from a

southern European

perspective

World Transport Policy \&

Practice

2/ 4 [1996] 38-46 forecast and observed traffic of 151 trunk road schemes (Sactra, 1994). A committee member, Philip Goodwin, has calculated that a new road gener ates an average 10 per cent more traffic the moment it opens.

According to an evaluati on related to the Ger man si tuation, a third of the annual traffic growth should be attributed to the construction of new roads (Pfeiderer and Dietrich, 1995).

This phenomenon has been detected al so in presence of new high speed trains lines. In Spain for example, the introduction of the Madrid-Seville, line has produced 300.000 trips per year (26 per cent of total) that would not have been made in absence of the new rail infrastructure (Estevan and Sanz, 1994).

Change the priority from hardware to software

In order to provide mobility services, in many situations it is cheaper and environmentally more friendly to explore other solutions than building new roads. Organizational measure, software-oriented strategies user charges can increase the efficiency of transport networks and reduce the need for new infrastructure.

\section{“...I t is cheaper and environmentally morefriendly to explore other solutions than building new roads..."}

The cost of this approach is usually much lower than that of the traditional strategy of new constructions. It may be useful, for this reason, to transfer the "least cost planning" procedure applied with success in USA in the energy field to the mobility sector.

This approach consists in comparing different options on the "demand side" through energy saving technologi es al ong with different power plant options in order to define the mix of solutions able to satisfy a forecasted demand increase with the least cost for the utility (or for the soci ety).

A similar approach could be appli ed also to transportation, evaluating the best way to provide mobility services rather than just considering the construction of new roads.

Rethinking economic co-operation to reduce good transport

The dominant transport policy in the E uropean Union consists in the adaptation of the existing national transport infrastructure into cross border networks in order to provi de access in Europe as a single country.
The proposed TEN (Trans European transport Networks) will absorb an incredible amount of money (400-500 billion ecus over the next 15 years, of which 10 per cent will be covered by European funds) and will have significant environmental impacts, while the effects on economic growth and employment are questionable.

J ust to concentrate on the global warming issue, it has been calculated that the programme will cause a rise in carbon dioxide emissions from the transport sector of 15-18 per cent above existing forecasts of 42 per cent increase by 2010 (Greenpeace, 1995).

Since these new connections should stimulate employment and economi c recovery, in particular in the less devel oped regions, it is important to verify how the projects really will reach these results.

A nalysing in particular road freight transport, we should note that the large majority of the exchanges in Europe are for desti nations shorter than $50 \mathrm{~km}$ (in Ger many this fraction covers 85 per cent of total).

The tendency, however, is to increase the accessi bility between di stant places and to substitute regional with supra-regional co-operation.

A clear example of the enlargement of the market area is given by the fact that while in the 1970s the I talian shops were selling only local mineral waters and other drinks, now these products travel over much larger distances. In an investigation of a few years ago, drinks represented 8 per cent of the total road freight transported over distances of more than $400 \mathrm{~km}$. The increase in travel is not only generated by the di stribution system but al so by the production logistics.

A striking example of the travels' derived by the actual distribution of production centres has been given analysing the di rect deliveries travel necessary to produce yogurt in the Stuttgart area in Ger many (Böge, 1995). A total length of $3,500 \mathrm{~km}$ is necessary to deliver all the ingredients necessary to produce the yogurt; a single $150 \mathrm{~g}$ pot implies $9.2 \mathrm{~m}$ of lorry movement with a fuel consumption equal to 2 per cent of the product wei ght to be sold. Considering a different territorial distribution of production centres that privileges the manufacturers nearest to the consumption area, a 67 per cent reduction in distances travelled could be achi eved, with a 75 per cent reduction in transport on motorways (Holzapfel, 1995).

In contrast with this example is equilibrium of peripherical regions based on the increase of inter-regional connections, 
Gianni Silvestrini

Road construction and

economic growth from a

southern European

perspective

World Transport Policy \&

Practice

2/ 4 [1996] 38-46 which will inevitably lead to an increase in transportion demand.

The effect of a dislocation of industries in peripheral regi ons has been studied in the Transport General PIan of Italy. A redistributi on of activities has been analysed in order to have 10 per cent of the demand of the nor ther $\mathrm{n}$ regions, at present satisfied by nor ther $n$ industries, supplied by souther $n$ industries, and 5 per cent of the souther $n$ demand, at present satisfied by the north, captured by local industries (PGT, 1988). By the year 2015, while the conventional scenari o consi dered a growth of freight transport of 130 per cent compared with the 1980 data, in the re-equilibrium scenario the increase was higher (+137 per cent).

\section{Different transport scenarios}

The contradiction between the inexorable transport growth and the environmental limits has recently led different gover nments to try to define new mobility policies.

In Ger many the Ministry of Transport has explored the possible traffic developments through the year 2010 after unification (Rothengatter, 1994). A conventional scenario was compared with an "intervention" scenario that includes capacity restraints in the road network, road pricing and higher costs for air transport. A significant effect in the modal split would be achieved in the

$\overline{\text { Table } 1}$

Volume of passenger transport in the year 2010 in Germany $(1988=100)$ for two different scenarios

\begin{tabular}{lcc}
\hline & Conventional scenario & Intervention scenario \\
\hline Car & 141 & 116 \\
Rail & 132 & 203 \\
Air & 241 & 206 \\
\hline
\end{tabular}

"intervention" scenario, but globally the mobility demand would still increases by 32 per cent (see Tablel).

In terms of car pass-km, a 41 per cent increase (compared with 1988) was evaluated for the conventional scenario, whilea smaller increase, 18 per cent, was calculated in the intervention scenario (a slight decrease, -3 per cent, considering only West Germany).

A similar evaluation has been made in The Netherlands with the elabor ation of a "E uropean Renaissance scenario" through the year 2015 (Figure 1). The increase in passenger mobility in this case is lower ( +19 per cent), while freight growth continues to be high (+83 per cent). It is important to note, however, that $\mathrm{CO}_{2}$ emissions are considered to decrease slightly in this scenario due to the introduction of high efficiency vehicles, bicycles... (CPB, 1992).

Is it possible to invert the trend to an increase of the road transport share?

Environmental problems, like congestion, noi se and pollution are more and more influencing the conventi onal transport policies, as recent deci sions in Austria, Switzerland and Califor nia demonstrate.

Austria and Switzerland have decided to introduce limits truck transit through their countries. As seen in Figure 2 a combination of rigid constraints on truck transit with an aggressive rail promotion strategy has created a high rail share in Switzerland (A eta, 1995). In the same figure it is also possi ble to see the effects, after 1985, of the Austrian limitation in truck transit. The recent decision by the Swiss gover nment to improve greatly the rail corridors (Neue A I pen transversale) will increase the share (by 2004 no

$\overline{\text { Figure } 1}$

Scenario for sustainable mobility in The Netherlands 1990-2015 $(1990=100)$

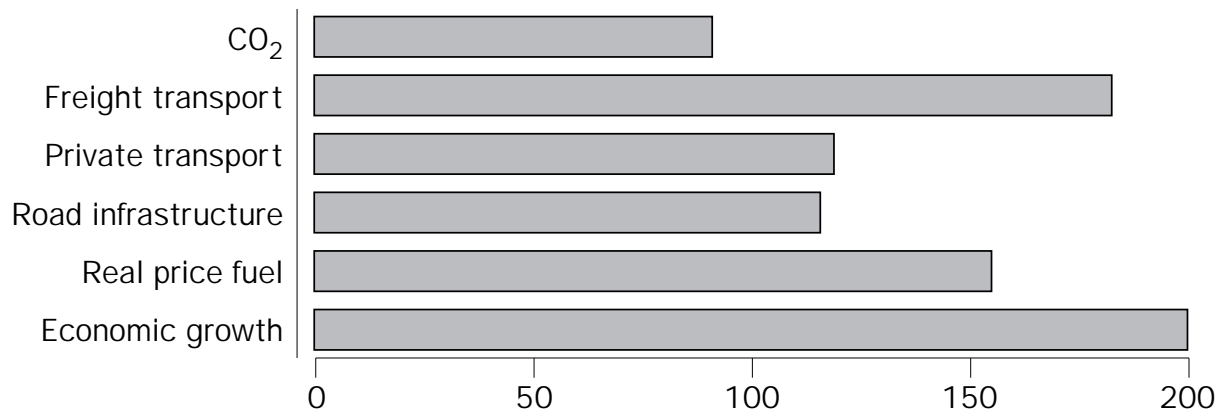




\begin{tabular}{l}
\hline Gianni Silvestrini \\
Road construction and \\
economic growth from a \\
southern European \\
perspective \\
World Transport Policy \& \\
Practice \\
2/ 4 [1996] 38-46
\end{tabular}

$\overline{\text { Figure } 2}$

Cross-Alps goods transport between northern Europe and Italy

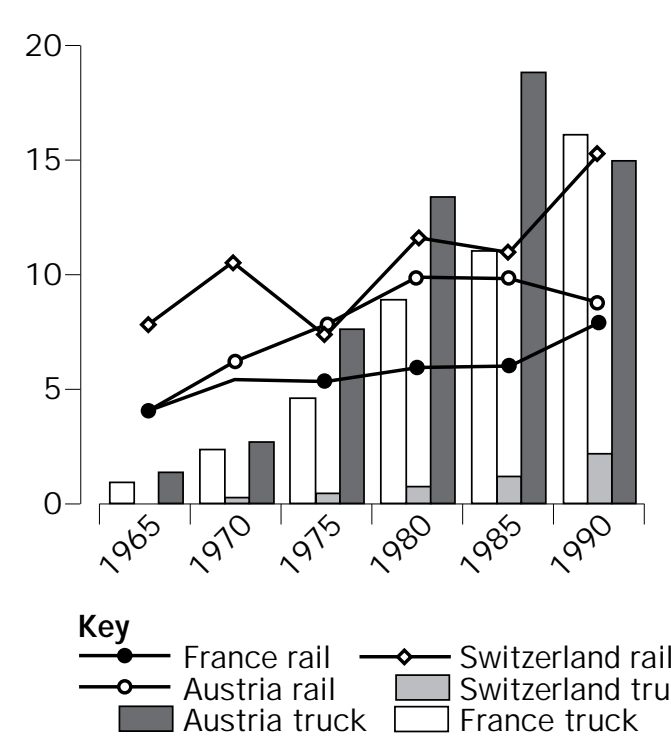

trucks will be all owed to pass through Switzerland, as a result of a 1994 referendum).

In Southern California the need to improve air quality influenced the transport policy. In 1992 the Los Angel es County Transportation Commission produced a " 30 years Integrated Transportati on Plan", in which 300 mi les of new urban and commuter rails were consi dered, at a cost of nearly $\$ 90 \mathrm{bil}-$ lion. This may be the beginning of a reversal in transport strategies in a region in which the complete dominati on by cars (Los Angeles had dismantled its $1,600 \mathrm{~km}$ tramway network) produces alarming air quality problems.

If these examples demonstrate how local environmental problems are increasingly influencing mobility policies, the transformation will be much more radical in the future as gover nments react to larger risks such as global warming. Even if there are the first signs of a redirection of transport policies, the situation has historically been very unbalanced, with a concentration on road building and a neglect of al ter native transport options.

For example the gover nment of the USA has spent, between 1958 and 1989, \$13 billion on freeways, al most ten times more than on railways. In western Europe during the 1970 s and the 1980s the investments in roads have been three times higher than in railways (Lowe, 1994)

It is i mportant to be aware that the redirection of economic resources in order to obtain visible results will be enor mous. For example, if in the UK 10 per cent of car trips should move to rail, this would represent a value of 50 billion $p-k m$ (passengers-kilometres), equivalent to a 125 per cent increase in $\mathrm{p}-\mathrm{km}$ trains. The costs of upgrading the trains and to building new lines would be on the order of 9 billion ecu, that is 0.2 ecu per $\mathrm{p}-\mathrm{km}$ transfer red from car to rail (Transnet, 1990).

Road building from a peripheral perspective

Even if a change of attenti on is emerging in the most advanced European countries (Sweden has decided to invest for the future the same amount of money on road and on rail infrastructures and Ger many intends by 2010 to invest more in rail than in roads, (Lowe, 1994), the strategy for the peripheral regi ons seems to reproduce the conventional distorted path that is consi dered unbearable in the other European countries.

For example analysing the funds (19 bilIion ecu) made available in the 1988-1993 period for transport to less devel oped countries by the European Investment Bank, the investments for railways were 40 per cent lower than those in roads.

Even more unbalanced is the situation of the European Uni on Cohesion Fund projects on transportation infrastructures. In 1993, three-quarters of the investments have been all ocated to road construction (Table II).

Figures 3 and 4 show, for the period 19851992, travellers by transport mode and the public investment in public infrastructure in Spain (M OPT, 1993). The correlation between the growth in road transport expenditures and the growth of road passengers is impressive

The same distortion is present in the Sicilian situation, that will be described in more detail with planned investments in road construction for the next decade 50 per cent higher than in rail road lines.

\section{$\overline{\text { Table II }}$}

Distribution of the European Union Cohesion Fund in the transport sector for 1993

\begin{tabular}{lcccc}
\hline & $\begin{array}{c}\text { Road } \\
\%\end{array}$ & $\begin{array}{c}\text { Rail } \\
\%\end{array}$ & $\begin{array}{c}\text { Ports } \\
\%\end{array}$ & $\begin{array}{c}\text { Airports } \\
\%\end{array}$ \\
\hline Spain & 70 & 15 & 2 & 12 \\
Portugal & 72 & 24 & 4 & \\
Greece & 69 & 13 & 3 & 15 \\
Ireland & 64 & 23 & 9 & 4 \\
\hline
\end{tabular}


Gianni Silvestrin

Road construction and

economic growth from a southern European

perspective

World Transport Policy \&

Practice

2/ 4 [1996] 38-46 $\overline{\text { Figure } 3}$
Travellers by transport mode in Spain (1985-1992)

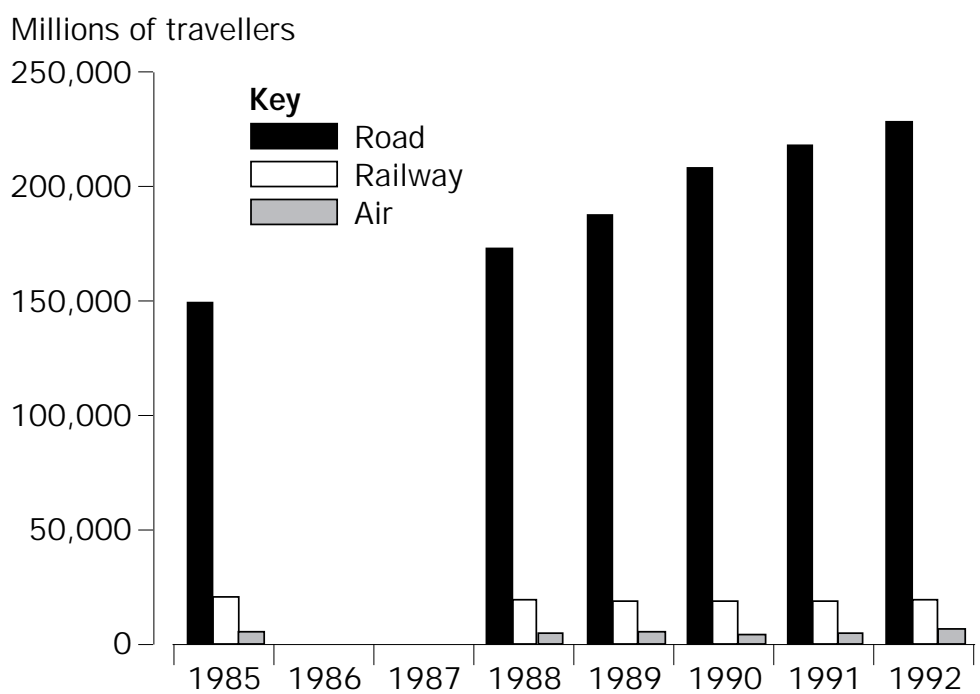

$\overline{\text { Figure } 4}$

Public investment in transport infrastructures in Spain (1985-1992)

Millions of pesetas

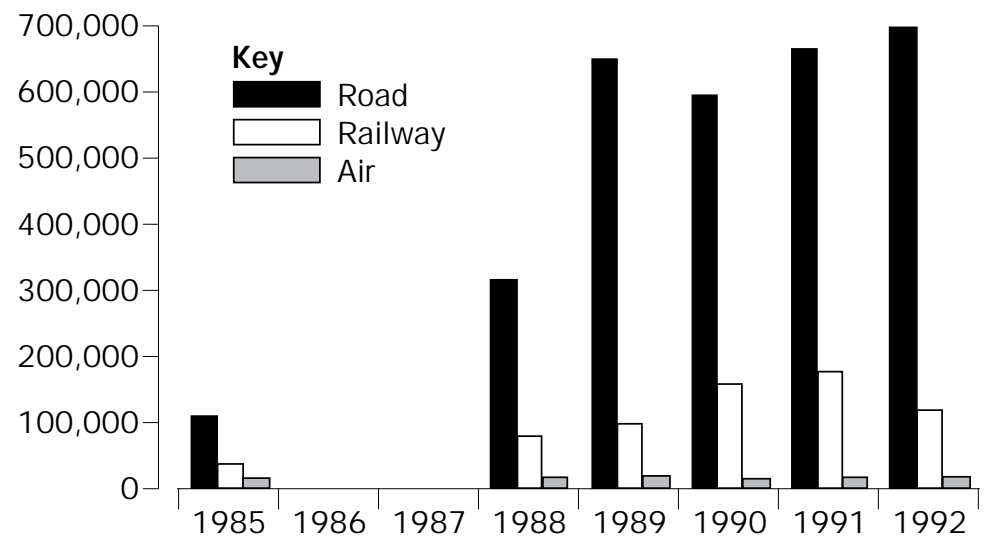

Proposals for new infrastructure do not always address serious transport problems. One of the risks of unplanned improvements is, in fact, to have serious over-capacity. This is the case, for example of the MadridBarcel ona corridor, where a highway, a freeway, nor mal roads, a rail line, a high-speed rail line and different air connections coexist, with the result that the provision is ten times higher than the real demand (Estevan and Sanz, 1994).

Are new roads really needed? The creati on of good connections with the centre is considered a major point for peripheral regi ons and this is partly true.
However, some attention should be paid to the different ways in which this can be achieved.

First of all, in some situations the best connection with the centre (especially for freight) could be given by sea and rail services. Two cases exemplify the vali dity of this assumption.

In Scotland 92 per cent of the journeys are within Scotland and, as a report has underlined, freight services through a di rect fer ry service to the European mainland would be more beneficial than a transit through Engl and and the Channel Tunnel (M CKinnon, 1992).

A similar conclusion can be obtained analysing the situati on of Si cily, an Italian peripheral region. Also in this case a direct connection with ferries or with combined transportation could represent a better al ter native than the proposed new infrastructures, like the construction of a bridge across the Messi na Strait, as will be better explained in the following paragraph (Figure 5).

According to these consi der ations, it should be concluded that at least part of the Trans European Networks proposed by the European Union should be rediscussed in the context of sustainable transportation.

A second aspect to be considered is the real efficacy of the introduction of reliable transport networks on regi onal devel opment.

Improving the road connection between a peripheral region and the centre will certainly be more effective for competitive than 
Gianni Silvestrini

Road construction and

economic growth from a

southern European

perspective

World Transport Policy \&

Practice

2/ 4 [1996] 38-46 for marginal industries. As the more competi tive industries are gener ally located in the central regions, an improvement of the transport facilities will at first favour the penetration of outsi de products.

Therefore, paradoxically, the presence of high level transport connections could damage the expansion of a regi onal network of activities. On the other hand, as it was al ready described with the yogurt case, a regional co-operation will lead to a more sustainable mobility.

\section{Periphery-centre relations: the case of Sicily}

The Sicilian situation is typical of many peripheral areas in which the public expenditure has the result of increasing the imports due to the limited internal industrial structure.

For example, from an increase of the demand of goods of the agro-food sector of 1 million ecu, only 340,000 ecu will flow to the Sicilian system with the creation of 40 new jobs (out of a total of 113 added employment PRS, (1991)).

This fact has to be consi dered when discussing the correct balance between the enlargement of the connections with the

\section{$\overline{\text { Figure } 5}$}

Location of the Messina Strait

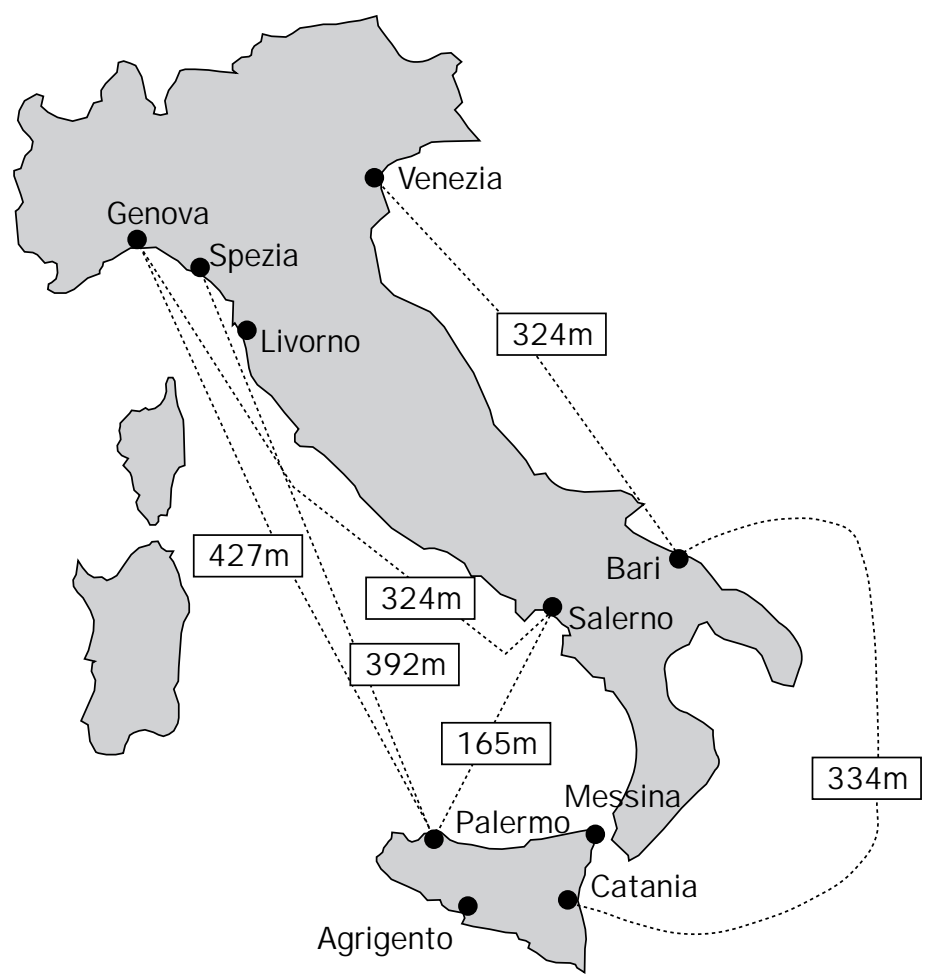

continent and the improvement of the inter nal transport network.

The bridge across the Strait of Messina A $n$ interesting example of the inter actions between the construction of new transportation infrastructures and regional economi es is given by the project of the bridge which should connect Si cily with the Calabria regi on in souther $n$ I taly. The infrastructure has been proposed in order to reduce the marginality of these per ipheral regi ons but, the transportation benefits will be minimal, while there are many strong counter indications for the project.

The proposal has been under active discussi on since 1971 when a public society was created in order to devel op the technical studi es and to analyse the economic and financial aspects of a connection between Si cily and Calabria. In 1987 the bridge solution was chosen between different technical options. A final decision on the construction of the bridge, however, has not yet been taken, given the very high costs of the infrastructure (on the order of at least 5 billion ecu).

This project is a typical example of misallocation of economic resources, not considering the environmental impacts of the structure which have been specifically criticized (Legambi ente, 1993).

First of all, the new infrastructure will only slightly improve the travel conditions, since 75 per cent of the trips have a length of more than $500 \mathrm{~km}$ and that the reduction in time (from 15 minutes to 1 hour) for long journeys is consi dered marginal, especially for frei ght transport (consi dering al so loading, unloading). For this reason the introduction of the bridge is not considered likely to have much effect on the flows between Sicily and the rest of I taly.

The evolution of traffic has been evaluated by $M$ archetti (1988), using the UMOT (unified mechanism of travel) model in connection with The Volterra-Lotka equations in order to grasp long-ter $\mathrm{m}$ trends. A ccording to this analysis, both freight and passenger demand will not significantly increase in presence of the bridge, unless completely different high-speed transport systems, like Maglevs, are considered, in which case the two connected towns, Reggio Cal abria and Messina, will form a unique metropolitan area (by the way, the planned bridge allows a maximum speed of $130 \mathrm{~km} / \mathrm{h}$, much less than the velocity consi dered in the Marchetti proposal). 
Gianni Silvestrini

Road construction and

economic growth from a

southern European

perspective

World Transport Policy \&

Practice

2/ 4 [1996] 38-46
A second critical aspect is given by the fact that the actual offer of transport through the ferries and aliscafis is much bigger than actual demand (Figure 6) and could easily match the demand forecasted for the next 20 30 years, consi dering al so the fact that 400 million ecu will be spent in any case to improve the sea connections.

A third criticism pointed to the unbalanced financial effort for this plan, consi dering the very low quality of the road and railway infrastructure in Sicily (only 7 per cent of the rail lines is double track and only 48 per cent of the lines are electrified).

A completely different "distributed" approach has been explored, with the activati on of direct connections between Sicilian and continental harbours. This solution would be much more economical and could greatly reduce both local and global environmental impacts, as was well demonstrated in

\section{$\overline{\text { Figure } 6}$}

Amount of transport by ferries through the Messina Strait

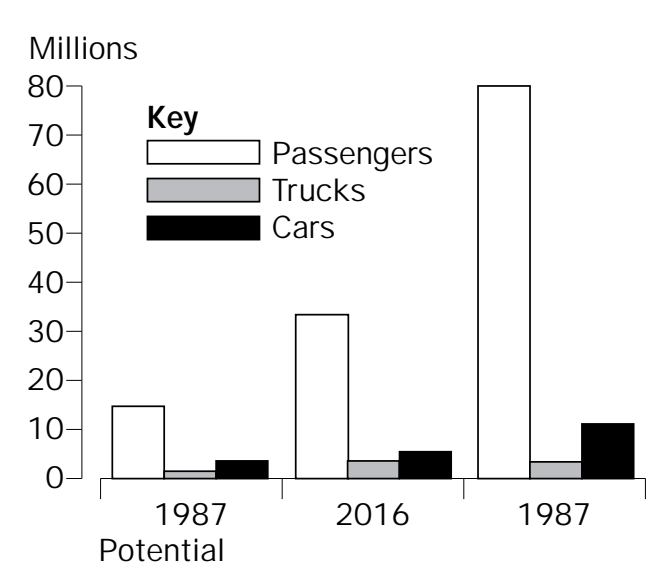

a study financed by the Nati onal Research Council (Oikos, 1985).

It would make much more sense to invest part of the money considered for the hightech bridge in a massive improvement of the Sicilian and Calabria rail road networks and harbours. This general upgrading will increase the accessi bility to the continent much more than the cathedral in the desert represented by the bridge.

Rationalization of combined transport Combined transport represents a very exciting alter native to long-r ange road freight transport from peripheral areas. In recent years it has grown rapidly in Sicily. But what is even more inter esting, is the large disparity between the void transport units arriving in Sicily and the leaving the island (Figure 7). This fact shows the great potential, in a context of a growing local economic development, of a more rational use of this solution to export Sicilian goods.

In 1994 1,5 million tons travelled using combi ned transport vectors. Of this quantity 79 per cent of the transport units leaving the island were void, while there was only 12 per cent of incoming units (FS, 1995).

\section{Internal connections}

The Sicilian road situation can be described as a network of over-si zed main routes with some very evident bottl enecks (beginning with the missing part of the PalermoMessina freeway).

The internal less important roads are on the contrary not adequate. The density of these muni cipal roads is less than half the average Italian value.

This lack of connections has been represented by the i mage of an "internal lake"

$\overline{\text { Figure } 7}$

Combined transport units moved from/ to Sicily

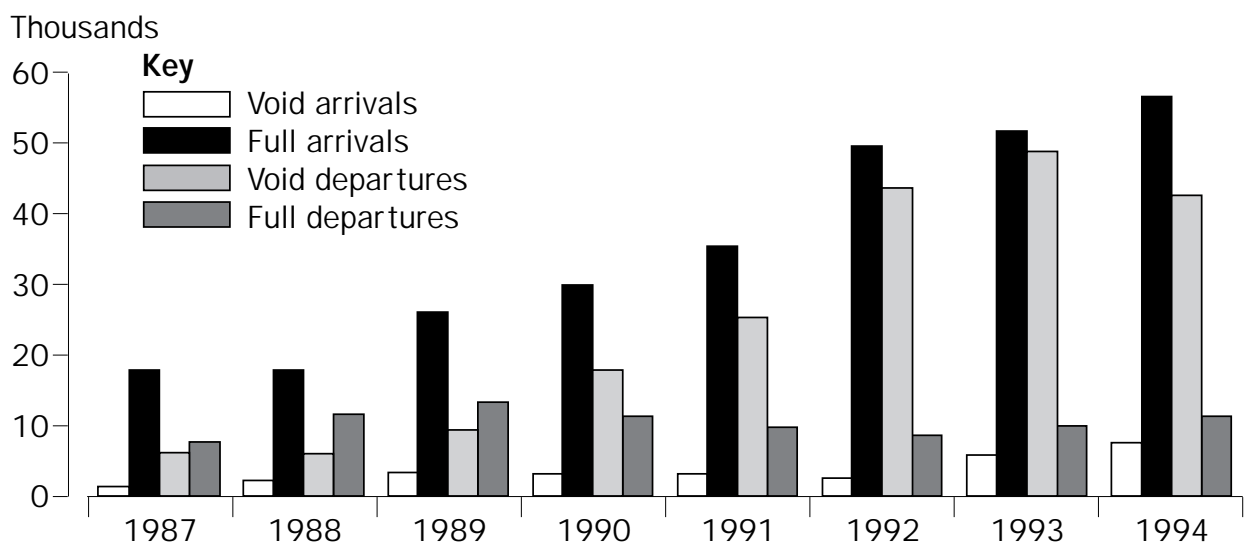


Gianni Silvestrini

Road construction and

economic growth from a

southern European

perspective

World Transport Policy \&

Practice

2/ 4 [1996] 38-46 due to the poor accessibility in the central part of the island. This weakness represents a great obstacle both to the creation of a regional industrial co-operation and to the development of tourist activities.

This situation is likely to change very much. Analysing the proposed investments contai ned in the Regional Transport Plan, the roads of lower i mportance will receive only one-third of the total road finance (PRT, 1991).

On the other hand, the combination of political and mafi a interests has lead, in the past, to the construction of roads, viaducts, and tunnels, many of which are not needed. It is no surprise that the density of highways and roads per square kilometre in Sicily is slightly higher than the Italian average.

The same result is obtained by the analysis of the transit data in different highways of north and south Italy in 1994 (Table III). The daily transit per km in Sicilian highways is less than half of the Italian average.

A ttention should of course be paid in order to improve internal mobility, but whatever is chosen must be sustainable.

A n example of two quite different solutions of a transport problem is given by the inadequate connection between the Sicilian towns of Paler mo and Agrigento (116km), guar anteed at present by an uncomfor table state road and a single track rail.

According to the regional government programmes, a completely new four-lane road should be built (partly passing through an ecologi cally sensitive ter ritory) with a cost of 500 million ecu. Moreover, a new airport should be added, with a location in the A grigento area (35 million ecu).

A complete different approach, proposed by the Rail Company, is based on the upgrading of the existing rail line that could connect Agrigento directly with the Paler mo Airport (100 million ecu) and on specific interventions in the road bottlenecks. This choice would be cheaper and give cor rect mobility answers in an environmentally sustainable way.

\section{$\overline{\text { Table III }}$}

Number of vehicles (thousands) travelling daily in 1994 in different segments of Italian highways

\begin{tabular}{cccc}
\hline \multicolumn{2}{c}{ North Italy } & \multicolumn{2}{c}{ Sicily } \\
Torino-Milano & Milano-Brescia & Messina-Catania & Messina-Palermo \\
\hline 85 & 196 & 50 & 38 \\
\hline
\end{tabular}

Conclusions

Conventional economic growth stimulates further demand for transportation infrastructure, which provides the pretext for further infrastructure expansion. This is particularly true for the construction of new roads, the sector in which the larger increases in mobility occur and that will induce envi ronmental i mpacts that will last for many decades.

This vicious circle should be inter rupted and a strong effort should be made in order to decouple economic development from transport growth.

If this target is to be achieved, all the strategic decisions involving different sectors (location of new industries, urban planning, construction of new infrastructures) should pass through an environmental assessment i mpact including specifically the issue of the contribution to global warming.

For peri pheral regions the transport policies should improve the possibility of a selfcentred devel opment. Regarding the connections with the central areas a preference, when possible, should be given to the sea or rail transport.

\section{References and further reading}

A eta (1995), Combined Transport: TheSustainableM odefor European Goods transport, Austrian Environmental Transport Association/VCO, Wien

Böge S. (1995), “The well travelled yoghurt pot: lessons for new freight transport policies and regional production", World Transport Policy \& Practice, Vol. 1 No. 1.

CPB (1992), Transport in The Netherlands up to 2015: A Scenario Approach, Central Planbureau, working paper No. 45, The Hague, P11MI.

Estevan A . and Sanz A . (1994), Hacia la Reconversion Ecologica del Transporteen Espana, Ministerio de Obras Publicas, Transportes y Medio A mbiente, Madrid.

FS (1995), Personal communication from Ferrovie dello Stato, Compartimento di Palermo.

Greenpeace (1995), M issing Greenlinks, Greenpeace Switzerland, Zurich.

Holzapfel, H. (1995), “Potential for ms of regi onal economic co-operation to reduce goods transport", World Transport Policy \& Practice, Vol. 1 No. 2.

Legambi ente (1993), Osservazi oni allo Studio di I mpatto Ambientale Relativo al Progetto di Massima del PonteSullo Stretto di Messina, Legambiente, Roma. 
Gianni Silvestrin

Road construction and

economic growth from a

southern European

perspective

World Transport Policy \&

Practice

2/ 4 [1996] 38-46
Lowe, M. (1994), Back on Track: The Global Rail Revival, Worldwatch Institute, Washington, DC.

Marchetti, C. (1988), Building Bridges and Tunnels: TheEffect on theEvolution of Traffic, SR-88-01, IIASA, Laxenburg, Austria.

McKinnon, A. (1992), “Manufacturing in a peripheral area", I nternational J ournal of Logistic Management, No. 3.

MOPT (1993), Los transportes y las Comunicaciones, Anuario 1992, Institute for the Studies of Transport and Communications, Ministry of Public Works and Transports, Madrid.

Oikos (1985), Sviluppo di I potesi Previsionali e Progettuali di Assetti Infrastrutturali edi Servizi di Trasporto Coerenti con I'Evoluzione Territorialedel Sistema Produttivo econ I'Assetto Urbano nelleA reeBolognese dello Stretto di Messina, Progetto Finalizzato Trasporti, National Research Council, Rome.
Pfeiderer, R. and Dietrich M. (1995), “New roads generate new traffic", World Transport Policy \& Practice, Vol. 1 No. 1.

PGT (1988), “II trasporto merci el'economia italiana", Piano Generale dei Trasporti, Roma.

PRS (1991), Piano Regionaledi Sviluppo, Regione Siciliana, Palermo.

PRT (1991), Piano Regionaledei Trasporti, Relazione generale, Regione Siciliana.

Rietveld, P. (1994), "Spatial economic impacts of transport infrastructure supply", Transportation Research, Vol. 28A No. 4.

Rothengatter, W. (1994), “Transport demand development in Ger many after the unificati on", Transportation Research, Vol 28 No. 6.

Sactra (1994), Trunk Roads and the Generation of Traffic, The Standing A dvisory Committee on Trunk Road Assessment, Department of Transport, London.

Transnet (1990), Energy Transport and Environment, Calvert's Press, London. 